\title{
Emerging (Bio)Sensing Technology for Assessing and Monitoring Freshwater Contamination - Methods and Applications
}

\author{
Raquel B. Queirós ${ }^{1,2}$, J.P. Noronha3, \\ P.V.S. Marques ${ }^{1}$ and M. Goreti F. Sales ${ }^{2}$ \\ ${ }^{1}$ INESC TEC (formerly INESC Porto) and Faculty of Sciences, University of Porto, \\ ${ }^{2}$ BioMark Sensor Research and ISEP/IPP - School of Engineering, \\ Polytechnic Institute of Porto, \\ ${ }^{3}$ REQUIMTE/CQFB and Faculty of Sciences and Technology of \\ University Nova de Lisboa, \\ Portugal
}

\section{Introduction}

Water is life and its preservation is not only a moral obligation but also a legal requirement. By 2030, global demands will exceed more than $40 \%$ the existing resources and more than a third of the world's population will have to deal with water shortages (European Environmental Agency [EEA], 2010). Climate change effects on water resources will not help. Efforts are being made throughout Europe towards a reduced and efficient water use and prevention of any further deterioration of the quality of water (Eurostat, European Comission [EC], 2010). The Water Framework Directive (EC, 2000) lays down provisions for monitoring, assessing and classifying water quality. Supporting this, the Drinking Water sets standards for 48 microbiological and chemical parameters that must be monitored and tested regularly $(\mathrm{EC}, 1998)$. The Bathing Water Directive also sets concentration limits for microbiological pollutants in inland and coastal bathing waters (EC, 2006) $)_{\llcorner}$addressing risks from algae and cyanobacteria contamination and faecal contamination, requiring immediate action, including the provision of information to the public, to prevent exposure. With these directives, among others, the European Union [EU] expects to offer its citizens, by 2015, fresh and coastal waters of good quality.

Freshwater quality is generally monitored with regard to chemical and microbiological parameters. Most regulated chemical parameters are monitored by more or less expensive but reliable techniques and some of which allow on-site analysis. The ease of access to such analytical procedures is reflected on the large amount of chemical data given by Water Information System for Europe [WISE] (EEA, 2011). Microbial parametric data are, on the contrary, more difficult to obtain. Microorganisms may be defined as those organisms that are not readily visible to the naked eye, requiring a microscope for detailed observation. These have a size range (maximum linear dimension) up to $200 \mu \mathrm{m}$, and vary from viruses, through bacteria and archea, to micro-algae, fungi and protozoa (Sigee, 2005). 
There are many different microorganisms that can pose serious risks to the environment and public health (Figure 1). In general, waterborne pathogens cause 10-20 million deaths and 200 million non-fatal infections each year (Leonard et al., 2003). They contribute to harmful effects either by a direct or indirect way: through the direct contact with the pathogen (when they are ingested by susceptible men or other living organisms) or by their metabolites like the toxic products excreted to water bodies. Some of these contaminants of microbiological origin are subject to limiting values in waters.

Legal requirements indicate cultured-based methods to monitor cell activity or highly sophisticated and expensive instrumental-based methods for metabolite detection/quantification. In general, these methods are cumbersome and take too long to produce the desired response; within that time the contamination can move/spread out, while users of recreational waters and possible consumers are at risk of contracting serious infections. Regardless of their sensitivity and selectivity these methods also are unsuitable for routine and on-site applications (An \& Carmichael, 1994; Health Protection Agency, 2005; International Organization for Standardization [ISO], 2005).

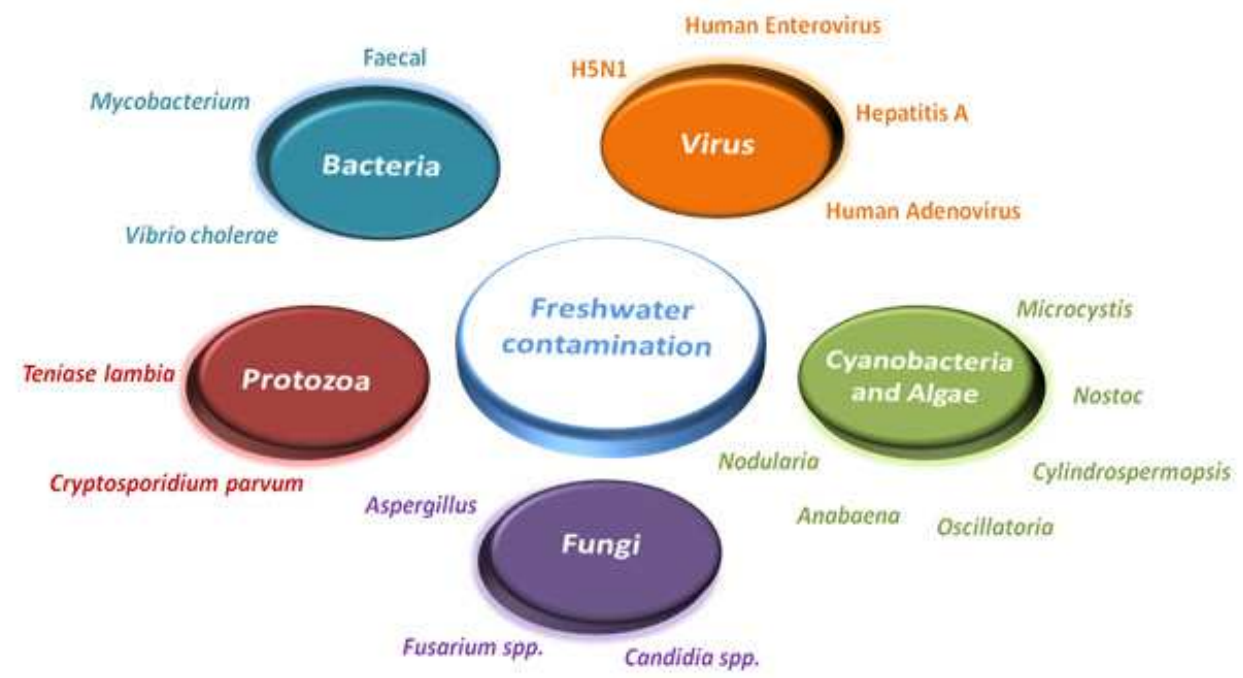

Fig. 1. Microorganisms contaminating freshwater.

Novel technologies for assessing and monitoring microbial water contamination are now becoming available. Biosensors are here of main interest (Figure 2). They have a captureprobe (or biorecognition element) on a standard transduction surface allowing on-site inexpensive determination. The biorecognition element (enzymes, cofactors, cells, antibodies, nucleic acids, or structured polymer) interacts with the target analyte, producing a physical-chemical change that is converted by the transducer into a detectable signal. This signal can be measured optically, mechanically, magnetically, thermally or electrically (Nayak et al., 2009; Su et al., 2011; Turner \& Piletsky, 2005; Vo-Dinh, 2007).

Optical or radiant transducers can be classified according to mode or scattering. Classification by mode includes absorption, emission or combination thereof (absorbance or 
transmission in Ultra-Violet [UV], Visible [Vis], or Infra-Red [IR] region of the spectrum, Attenuated Total Reflectance [ATR], Evanescent Field, Surface Plasmon Resonance [SPR], Luminescence, and Photoemission). Classification by scattering consists on phase change, polarization, absorption and opto-thermal effect (Raman, Ellipsometry, SPR and PhotoAcoustic effect). Mechanical transducers are often called frequency transducers and include Surface Acoustic Wave [SAW], piezoelectric oscillators, and Quartz Crystal Microbalance [QCM]. Magnetic transducers are Nuclear Magnetic Resonance [NMR] and mass spectrometry detection systems. Thermal transducers include calorimetric systems. Electrical transducers can be called electrochemical transducers when the electrical measure is evaluated in a solution. The classification of electric transducers by mode can include voltage (Potenciometric) or current transducers (Amperometric), current-voltage transducers (Voltammetric, Field Effect Transistors [FETs], Metal Oxide Semiconductor [MOS], charge transfer and resistance transducers (coulometric, chemiresistors, ion mobility, and mass spectrometry) and dielectricity transducers (Capacity systems) (Spichiger-Keller, 1998).

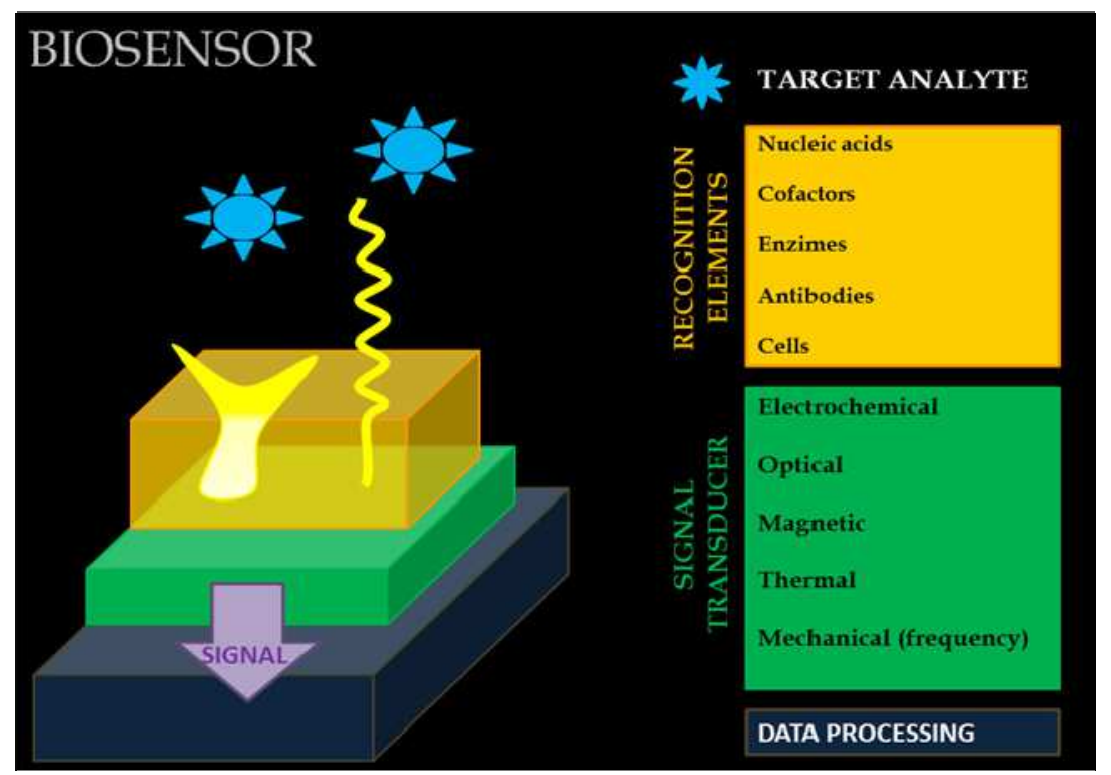

Fig. 2. General biosensor scheme.

Biosensors must meet essential requirements for a successful application. First, the output signal must be of relevance. The biosensor must be accurate and sensitive, providing zero "false-positives" and few "false negatives" and should be reproducible. Moreover the biosensor must be specific, discriminate between the target organism and other organisms. The response time of the biosensor must be inferior to the analytical reference methods, ideally providing a "real-time" response. Also, it must be physically robust and must be able to resist temperature, $\mathrm{pH}$, and ionic strength changes as well as be insensitive to other environmental interferences. The assay should require minimal operator skills for routine detection. One of the most important criteria is the cost of either manufacture, running and 
life cost. Finally, the biosensing assay must be accurate against standard techniques (Leonard et al. 2003).

Biosensors have been applied by now to the most important forms of microbial contamination: virus, protozoa, bacteria and their toxins, harmful algae and fungi. This chapter will review emerging biosensing technology, methods and applications for assessing and monitoring microbial water contamination. It will focus the development of cost-effective on-site methods, based on biosensing devices that show the potential to complement both laboratory-based and field analytical methods. It will be structured according to biorecognition elements used in the biosensing system, and quote the microorganisms, metabolites or species that are a potential risk to humans; legal requirements; and emerging issues in water and infectious disease.

\section{Virus biosensors}

The most important waterborne viruses belong to Enteric viruses [EV]. Enterovirus, Hepatitis A virus, Noroviruses, Coxsackie viruses A and B and Rotaviruses are present in gastrointestinal tract of contaminated individuals and are eliminated through feces in larger quantities. Due to its incomplete removal from sewage (even after chlorination) EV are likely to be transmitted to humans from contaminated drinking water (Tavares, 2005). These pathogens can cause a variety of symptoms such as, non-bacterial gastroenteritis, infectious hepatitis, myocarditis and aseptic meningitis. EV can remain viable several months in water in adverse conditions (Tavares et al., 2005; Gilgen et al., 1997).

The most common assays for virus detection use antibody-based methods such as EnzymeLinked ImmunoSorbant Assay [ELISA] (Bao et al. 2001), fluorescent antibody assays (Barenfanger et al., 2000) and serologic testing (O'Shea et al., 2005). PCR assays are frequently used as complement technique to improve the detection of low concentration of virus (Henkel et al., 1997), despite being a costly and laborious technique. Several authors (Brassard et al., 2005; Gilgen et al. 1997; Soule et al., 2000) presented Reverse Transcriptase Polymerase Chain Reaction [RT-PCR] as sensitive and efficient method for detection of few EV. Since these diagnostic methods are generally unwieldy and often have limited sensitivity, a variety of new virus detection methods, including microcantilevers (Ilic et al., 2004), evanescent wave biosensors (Donaldson et al., 2004), immunosorbant electron microscopy (Zheng et al., 1999) and atomic force microscopy (Kuznetsov et al., 2005), have emerged to conquer these limitations.

Avian influenza virus [AIV], also known as H5N1, is considered by World Health Organization [WHO] an emerging issue and a potential risk of infection and recommends the monitoring of this virus in waters (WHO \& WASH Inter Agency Group, 2007). The natural reservoirs of $\mathrm{H} 5 \mathrm{~N} 1$ virus are wild waterfowls; these birds may excret large quantities of the virus in their feces as well as in the saliva and nasal secretions. Infected migratory waterfowl may then enter water environments where the birds gather and transmit the low pathogenicity virus to other migratory waterfowl and to domestic birds. During replication, the virus can mutate and highly pathogenic avian influenza [HPAI] strains may occur. The main concern with respect to the HPAI H5N1 virus is that it may change into a form that is highly infectious for humans and that spreads easily from person to person (WHO, 2007). 
AIV can persist for extended periods of time. H5N1 has been isolated from unconcentrated waters from lakes in Canada, United States and Hong Kong. There are no quantitative data available on levels of H5N1 virus in lake water where waterfowl gather, although its detection in unconcentrated waters and in small sample volumes suggest relatively high levels. Besides direct deposition of faeces into lake waters by migratory waterfowl, it has been suggested that faecal waste from duck and chicken farms may spread to bodies of water via wind, surface runoff or possibly enter groundwater through disposal and composting of waste on poultry farms (WHO, 2007).

Some authors reported a few new biosensors approaches for the rapid detection of H5N1 virus using impedance measurement of immuno-reaction coupled with red blood cells amplification (Lassiter et al., 2009; Lum \& Li, 2010), interferometric immunobiosensor (Xu et al., 2007) and electrochemical-aptamer based biosensor (Liu et al., 2011). Lum \& Li developed an impedimetric biosensor for the detection of AIV. The biosensor is composed by immunomagnetic nanoparticles [NPs], a microfluidic chip and an interdigitated microelectrode for impedance measurement. A polyclonal antibody against N1 subtype was immobilized on the surface of the microelectrode to specifically bind H5N1 virus. Therefore, chicken red blood cells were used as biolabels to attach H5N1 captured on the microelectrode to amplify impedimetric signals. A second antibody, also used against N1, offered greater specificity and reliability than the previous one. The results of this study showed that the biosensor was able to detect AIV in less than 2 hours (Lum \& Li, 2010).

An optical interferometric waveguide immunoassay for direct and label-less detection of avian influenza virus is described by $\mathrm{Xu}$ et al., 2007. The assay is based on refraction index changes that occur upon binding of virus particles to antigen specific antibodies on the waveguide surface. Three virus subtypes were tested using both monoclonal and polyclonal capture antibodies. The detection limits were as low as $0.0005 \mathrm{HA}^{\mathrm{H}}$ units $\mathrm{mL}^{-1}$ (Xu et al., 2007). Liu et al. developed an electrochemical method for the detection of avian influenza virus using and aptamar of DeoxyriboNucleic Acid [DNA] as recognition element immobilized on a hybrid nanomaterial-modified electrode. The modified electrode was assembled with multi-walled carbon nanotubes [MWNT], polypyrrole nanowires [PPNWs] and AuNPs. The detection limit found was $4.3 \times 10^{-13} \mathrm{M}$. These studies showed that the new hybrid nanomaterial MWNT/PPNWs/AgNPs and the DNA aptamer could be used to fabricate an electrochemical biosensor for gene sequence detection (Liu et al., 2011).

A spectroscopic assay based on Surface Enhanced Raman Scattering [SERS] using silver nanorod array substrates allowing the rapid detection of several human respiratory viruses with a high degree of sensitivity and specificity was developed by Shanmukh et al.. This novel SERS assay can detect spectral differences between viruses, viral strains and viruses with gene deletions in biological media. The method provides rapid detection and characterization of viruses generating reproducible spectra without viral manipulation (Shanmukh et al., 2006).

Persistent infection with hepatitis B virus [HBV] is a major health problem worldwide and may lead to chronic hepatitis, cirrhosis and primary liver cancer (Ye et al., 2003). The detection of HBV DNA in the serum of patient is becoming an important tool in the diagnosis of HBV infection. Two electrochemical detection methods based on DNA hydridization for detection of Hepatitis B viruses were reported by (Erdem et al., 2000 and Ye et al., 2003). 
Varíola Virus, also call Smallpox virus [SpV], was irradicated in 1977 but with the increase of unprotected population this virus became an ideal warfare agent. Donaldson and coworkers developed a sensitive and rapid real time immunoassay to detect $\mathrm{SpV}$ (Donaldson et al., 2004). It consisted in a polystyrene optical waveguide coated with streptavidin where anti-Vaccinia antibody was attached as a biorecognition element. The detection was performed by a commercial single wavelength fluorometer designed for evanescent wave fluoroimmunoassays. The biosensor was able to detect a minimum of $2.5 \times 10^{5} \mathrm{pfu}$ (pockforming units) $/ \mathrm{ml}$ of vaccinia virus in seeded throat culture swab specimens (Donaldson, 2004).

But other viruses have been detected rapidly by using biosensing technology. For example, immunosorbent electron microscopy was used to quantify recombinant baculovirusgenerated bluetongue virus [BTV] core-like particles in either purified preparations or lysates of recombinant baculovirus-infected cells. The capture was the anti-BTV VP7 monoclonal antibody [MAb]. This technique is simple, rapid and accurate for the quantification of virus produced in large scale in vitro systems (Zheng et al., 1999).

Another example is the use of Atomic Force Microscopy [AFM], under dynamic conditions, for imaging single-stranded genomic RiboNucleic Acid [RNA] from four icosahedral viruses, in which the RNA was observed to unfold (Kuznetsov et al., 2005).

\section{Bacteria biosensors}

Bacteria are the major pathogen responsible for water-borne disease. Cholera, typhoid fever, bacillary dysentery, leptospirosis and gastroenteriris are some examples of waterborne diseases caused by Vibrio cholera, Salmonella typhi, Shigella spp., Leptospira spp., and Enteropathogenic Escherichia coli [EPEC] (Ashbolt, 2004).

Table 1 resumes the latest screening methods for waterborne bacteria; capture and detection methods, limit of detection [LOD] and range of detection are compared (Baudart \& Lebaron, 2010; Bharadwaj et al., 2011; Bruno et al., 2010; Chen et al., 2008; Duplan et al., 2011; Fu et al., 2010; Geng et al., 2011; Guven et al., 2011; Huang et al., 2008, 2011; Karsunke et al., 2009; Kwon et al., 2010; Li et al., 2011A; Luo et al., 2010; Miranda-Castro et al., 2009; Park et al. 2008; Sun et al., 2009; Wang et al., 2009; Wilbeboer et al., 2010; Wolter et al., 2008; Yoon et al., 2009; Yu et al., 2009; Xue et al., 2009).

Pathogens transmitted via water are mostly of faecal source (Ashbolt, 2004). Pathogenic E. coli strains are responsible for infection of the enteric, urinary, pulmonary and nervous systems. E. coli infection is usually transmitted through consumption of contaminated water or food. The routine detection methods for these microorganisms are based on Colony Forming Units [CFUs] count requiring selective culture, or biochemical and serological characterizations. Although bacterial detection by these methods is sensitive and selective, days are needed to get a result. Besides, these methods are costly and time consuming. Because of its great importance as faecal contaminant indicator in waters, the development of biosensors to detect and quantify $E$. coli has been extensively studied and there are a very large number of new methods and improvements to reference methods (Choi et al., 2007; Deobagkar et al., 2005; Gau et al., 2001; Yáñez et al., 2006; Liu \& Li, 2002; Simpson \& Lim 2005; Tang et al., 2006; Yoo et al., 2007; Yu et al., 2009). 
Emerging (Bio)Sensing Technology for

\begin{tabular}{|c|c|c|c|c|c|c|}
\hline \multirow{2}{*}{ Bacteria } & \multirow{2}{*}{ Strain } & \multicolumn{2}{|c|}{ Methods } & \multirow{2}{*}{ LOD } & \multirow{2}{*}{ Detection range } & \multirow{2}{*}{ References } \\
\hline & & Capture & Transduction & & & \\
\hline E. coli & $\mathrm{O} 157: \mathrm{H7}$ & Immunological & Electrochemical & $10^{2} \mathrm{CFU} \mathrm{mL}^{-1}$ & $10^{2}-10^{5} \mathrm{CFU} \mathrm{mL}^{-1}$ & Yu et al., 2009 \\
\hline E. coli & $\mathrm{O} 157: \mathrm{H} 7$ & Nucleic acid & Electrochemical & $0.5 \mathrm{nmol} \mathrm{L}^{-1}$ & - & Wang et al., 2009 \\
\hline E. coli & ATCC 8739 & Nucleic acid & Optical & $30 \mathrm{CFU} \mathrm{mL}^{-1}$ & $30-3 \times 10^{4} \mathrm{CFU} \mathrm{mL} L^{-1}$ & Bruno et al., 2010 \\
\hline E. coli & unspecified & Nucleic acid & Electrochemical & 50 cells $\mathrm{mL}^{-1}$ & $1.0 \times 10^{2}-2.0 \times 10^{3}$ cells $\mathrm{mL}^{-1}$ & Geng et al., 2011 \\
\hline E. coli & K12 & Immunological & Optical & $10^{4} \mathrm{CFU} \mathrm{mL}^{-1}$ & $10^{2}-10^{6} \mathrm{CFU} \mathrm{mL}^{-1}$ & Duplan et al., 2011 \\
\hline E. coli & $\mathrm{O} 157: \mathrm{H7}$ & Immunological & Electrical & $61 \mathrm{CFU} \mathrm{mL}{ }^{-1}$ & $0-10^{4} \mathrm{CFU} \mathrm{mL}{ }^{-1}$ & Luo et al., 2010 \\
\hline E. coli & $\mathrm{O} 157: \mathrm{H7}$ & Nucleic acid & Mechanical & $1.2 \times 10^{2} \mathrm{CFU} \mathrm{mL} \mathrm{m}^{-1}$ & $10^{2}-10^{6} \mathrm{CFU} \mathrm{mL}^{-1}$ & Chen et al., 2008 \\
\hline E. coli & ATCC 15597 & Immunological & Optical & $10 \mathrm{CFU} \mathrm{mL} \mathrm{m}^{-1}$ & $10-10^{7} \mathrm{CFU}$ mL- 1 & Yoon et al., 2009 \\
\hline E. coli & unspecified & Immunological & Optical & $8 \mathrm{CFU} \mathrm{mL} L^{-1}$ & $10^{1}-10^{4}$ CFU mL-1 & Guven et al., 2011 \\
\hline E. coli & several & Nucleic acid & Optical & 15 culturable $E$. coli $(100 \mathrm{~mL})^{-1}$ & 35 and 145 viable E. coli $(100 \mathrm{~mL})^{-1}$ & Baudart \& Lebaron, 2010 \\
\hline E. coli & DSM 30083 & Enzimatic & Optical & $7 \mathrm{CFU} \mathrm{mL}^{-1}$ & $100-10^{8} \mathrm{CFU} \mathrm{mL}^{-1}$ & Wildeboer et al., 2010 \\
\hline E. coli & АCTT 25922 & Nucleic acid & Mechanical & 8 Cells $(800 \mathrm{~mL})^{-1}$ & - & Sun et al., 2009 \\
\hline E. coli & K12 & Immunological & Optical & $\begin{array}{c}100 \mathrm{CFU} \mathrm{mL}^{-1} \text { ( } 33 \% \text { Ab coverage) } \\
\mathrm{CFU} \mathrm{mL}^{-1} \text { (50\% and } 100 \% \mathrm{Ab} \\
\text { coverage) }\end{array}$ & - & Kwon et al., 2010 \\
\hline E. coli & BD2399 & Immunological & Mechanical & $10^{5} \mathrm{CFU} \mathrm{mL}^{-1}$ & $5 \times 10^{4}-5 \times 10^{9} \mathrm{CFU} \mathrm{mL}^{-1}$ & Fu et al., 2010 \\
\hline E. coli & DH5a & Nucleic acid & Electrochemical & 5 CFU mL-1 & $1 \times 10^{3}-5 \times 10^{5} \mathrm{CFU} \mathrm{mL}^{-1}$ & Li et al., 2011 \\
\hline E. coli & ATCC 35218 & Immunological & Optical & $<1000 \mathrm{CFU} \mathrm{mL}-1$ & $10^{1}-10^{8} \mathrm{CFU} \mathrm{mL}^{-1}$ & Bharadwaj et al., 2011 \\
\hline E. coli & unspecified & TGA & Optical & $10^{2} \mathrm{CFU} \mathrm{mL}^{-1}$ & $10^{2}-10^{7} \mathrm{CFU} \mathrm{mL}^{-1}$ & Xue et al., 2009 \\
\hline E. coli & $\mathrm{O} 157: \mathrm{H} 7$ & Immunological & Optical & $1.8 \times 10^{3} \mathrm{CFU} \mathrm{mL}^{-1}$ & $1.8 \times 10^{3}-1.8 \times 10^{8} \mathrm{CFU} \mathrm{mL} L^{-1}$ & Park et al., 2008 \\
\hline E. coli & $\mathrm{O} 157: \mathrm{H} 7$ & Immunological & Optical & $\begin{array}{l}1 \times 10^{4} \text { cells } \mathrm{mL}^{-1} \text { (single) } \\
3 \times 10^{3} \text { cells mL }{ }^{-1} \text { (multi) }\end{array}$ & $\begin{array}{l}1 \times 10^{4}-1 \times 10^{6} \text { cells } \mathrm{mL}^{-1} \text { (single) } \\
3 \times 10^{4}-3 \times 10^{6} \text { cells } \mathrm{mL}^{-1} \text { (multi) }\end{array}$ & Wolter et al., 2008 \\
\hline E. coli & O157:H7 & Immunological & Optical & $1.8 \times 10^{4}$ cells $\mathrm{mL}^{-1}$ & $8.5 \times 10^{4}-3.7 \times 10^{6}$ cells $\mathrm{mL}^{-1}$ & Karsunke et al., 2009 \\
\hline E. coli & $\mathrm{O} 157: \mathrm{H} 7$ & PU & Mechanical & $2 \times 10^{2}$ cells $\mathrm{mL}^{? 1}$ & $2 \times 10^{2}-3 \times 10^{6}$ cells ml $^{72}$ & Huang et al., 2008 \\
\hline E. coli & K12 ER2925 & Immunological & Electrical & $10 \mathrm{cfu} \mathrm{mL} L^{-1}$ & $0-10^{5} \mathrm{cfu} \mathrm{mL}^{-1}$ & Huang et al., 2010 \\
\hline Vibrio Chorela & O1 & Immunological & Optical & $1 \times 10^{3} \mathrm{CFU} \mathrm{mL}^{-1}$ & $1 \times 10^{3}-1 \times 10^{7} \mathrm{CFU} \mathrm{mL} \mathrm{m}^{-1}$ & Sungkanak et al., 2010 \\
\hline Vibrio Chorela & O1; O139 & Immunological & Optical & $\begin{array}{c}10^{8} \mathrm{CFU} \mathrm{mL}^{-1} \text { (O1) (WOE) } \\
10^{7} \mathrm{CFU} \mathrm{mL}^{-1} \text { (O139) (WOE) } \\
10^{2} \mathrm{CFU} \mathrm{mL} \text { (O1; }^{-1} \text { (O) (WE) }\end{array}$ & $10^{1}-10^{8} \mathrm{CFU} \mathrm{mL}^{-1}$ & Yu et al., 2011 \\
\hline Vibrio Chorela & several & Nucleic acid & Optical & $10 \mathrm{CFU} \mathrm{mL} \mathrm{L}^{-1}$ & $10-10^{6} \mathrm{CFU} \mathrm{mL} \mathrm{m}^{-1}$ & Zhou et al., 2011 \\
\hline Leptospira interrogans & several & Nucleic acid & Optical & $10 \mathrm{CFU} \mathrm{mL}{ }^{-1}$ & $10-10^{6} \mathrm{CFU} \mathrm{mL} \mathrm{m}^{-1}$ & Zhou et al., 2011 \\
\hline Salmonella spp. & several & Nucleic acid & Optical & $1 \mathrm{CFU} \mathrm{mL} L^{-1}$ & $10-10^{6} \mathrm{CFU} \mathrm{mL} L^{-1}$ & Zhou et al., 2011 \\
\hline Salmonella typhimurium & ATCC 14028 & Immunological & Optical & $3 \times 10^{6}$ cells mL- 1 (single/multi) & $\begin{array}{l}3 \times 10^{6}-3 \times 10^{8} \text { cells mL }{ }^{-1} \text { (single) } \\
3 \times 10^{6}-1 \times 10^{9} \text { cells mL }{ }^{-1} \text { (multi) }\end{array}$ & Wolter et al., 2008 \\
\hline Salmonella typhimurium & ATCC 14028 & Immunological & Optical & $2.0 \times 10^{7}$ cells $\mathrm{mL}^{-1}$ & $5 \times 10^{7}-1.1 \times 10^{9}$ cells mL $^{-1}$ & Karsunke et al., 2009 \\
\hline Salmonella typhimurium & unspecified & Immunological & Mechanical & $5 \times 10^{3} \mathrm{CFU} \mathrm{mL} \mathrm{m}^{-1}$ & $5 \times 10^{1}-5 \times 10^{8} \mathrm{CFU} \mathrm{mL}^{-1}$ & Guntupalli et al., 2007 \\
\hline Mycobacterium sp. & $\mathrm{H} 37 \mathrm{rv}$ & Nucleic acid & Electrochemical & $1.25 \mathrm{ng} \mathrm{mL}^{-1}$ & $1.25-50 \mathrm{ng} \mathrm{mL}^{-1}$ & $\begin{array}{l}\text { Thiruppathiraja et al., } \\
\qquad 2011\end{array}$ \\
\hline
\end{tabular}

LOD - Limit Of Detection; WE - With Enrichment; WOE - WithOut Enrichment. ¿ CFU - Colony Form Unit; $\mathrm{Ab}$ - Antibody.

Table 1. Latest screening techniques for bacteria detection in waters.

The immunological methods are the most widely used as recognition methods (Bharadwaj et al., 2011; Duplan et al., 2001; Fu et al., 2010; Guven et al., 2011; Huang et al., 2011; Karsunke et al., 2009; Know et al., 2010; Luo et al., 2010; Park et al., 2008; Wolter et al., 2008; Yoon et al., 2009; Yu et al. 2009), but nucleic acid capture probe are starting to gain some 
importance in the field (Baudart \& Lebaron, 2010; Bruno et al., 2010; Chen et al., 2008; Geng et al., 2011; Li et al., 2011; Sun et al., 2009; Wang et al., 2009). The use of aptamers instead of antibodies [Abs] as capture probes are increasing due to the advantages they present against Abs. Despite its high specificity and affinity, aptamers offer higher chemically stability and can be selected in vitro for a specific target, ranging from small molecules to large proteins and even cells. Moreover, once selected, aptamers can be synthesized with high reproducibility and purity from commercial sources. Furthermore, aptamers often undergo significant conformational changes upon target binding. This offers great flexibility in the design of novel biosensors with high detection sensitivity and selectivity (Song et al., 2008).

Bruno et al. described a Fluorescence Resonance Energy Transfer [FRET]-Aptamers assay applied to E. coli detection. In this assay, 25 reverse and 25 forward aptamer candidate sequences against $E$. coli were tested and compared in order to select the most sensitive to SPR and competitive-FRET analysis (Bruno et al., 2010). An iron oxide $\left[\mathrm{Fe}_{2} \mathrm{O}_{3}\right]$ gold $[\mathrm{Au}] \mathrm{core} /$ shell nanoparticle-based electrochemical DNA biosensor was developed for the amperometric detection of $E$. coli by Li et. al., 2011A The assay doesn't require any amplification step and the lowest detection value found was $5 \mathrm{CFU} \mathrm{mL}^{-1}$ of $E$. coli after $4.0 \mathrm{~h}$ of incubation (Li et al., 2011A). Another aptamer-based biosensor using magnetic particles was reported by Geng et al., 2011. This work included cobalt NPs and an enrichment process was necessary to find $10 \mathrm{E}$. coli cells $\mathrm{mL}^{-1}$ in real water samples by differential pulse voltammetry.

A flow piezoelectric biosensor based on synthesized thiolated probe specific to E. coli O157:H7 eaeA gene was immobilized onto the piezoelectric biosensor surface. Then, DNA hybridization was induced by exposing the immobilized probe to the E. coli O157:H7 eaeA gene fragment, resulting in a mass change and a consequent frequency shift of the piezoelectric biosensor. A second thiolated probe complementary to the target sequence was conjugated to the AuNPs to amplify the frequency change of the piezoelectric biosensor. The products amplified from concentrations of $1.2 \times 10^{2}$ CFU $\mathrm{mL}^{-1}$ of E. coli O157:H7 were detectable by the piezoelectric biosensor (Chen et al., 2008).

Sun et al. described a nano silver Indium Tin Oxide [ITO]-coated piezoelectric quartz crystal [PQC] electrode using DNA hybridization to detect E. coli cells. Neutravidin and a biotinylated probe were loaded at nano silver ITO-coated PQC and binding ratio was assessed. The binding ratio between the neutravidin and biotinylated DNA probe is increased from 1.00:1.76 of normal PQC to 1.00:3.01 using the nano-silver[Ag]-modified electrode, leading to an increase of more than $71 \%$ of the binding capacity of neutravidin to biotinylated DNA probes and an enhancement of 3.3 times for binding complementary DNA onto the nano-Ag-modified neutravidin/biotinylated DNA PQC biosensor. Under the optimized conditions, the detection limit was $0.4 \mathrm{ng} / \mathrm{L}$ for DNA Polymerase Chain Reaction [PCR] products or 8 E. coli cells in $800 \mathrm{~mL}$ in order to detect a single E. coli (Sun et al., 2009).

Magnetoelastic biosensors are based on the principle of change in the frequency of magnetoelastic materials (Nayak et al., 2009). Fu et al. developed a magnetostrictive microcantilever using physical absorption as detection system and an $\mathrm{Ab}$ against $E$. coli immobilized onto the surface of the microcantilever to form a biosensor. It was found a detection limit of $10^{5} \mathrm{CFU} \mathrm{mL-1}$ for a microcantilever with the size of $1.5 \mathrm{~mm} \times 0.8 \mathrm{~mm} \times 35 \mu \mathrm{m}$ (Fu et al., 2010). 
Immuno-optical biosensors are largely the most detection systems used and many different approaches are developed. A poly(ethylene glycol) [PEG] hydrogel based microchip with patterned nanoporous aluminum oxide membrane $[\mathrm{AOM}]$ for bacteria fast patterning and detection with low frequency impedance spectrum was reported by $\mathrm{Yu}$ et al. The PEG hydrogel micropatterns on the saline-modified nanoporous alumina surface created controlled spatial distribution of hydrophobic and hydrophilic regions. These microwell arrays were composed of hydrophilic PEG sidewalls and hydrophobic silane-modified AOM bottom. Abs against E. coli were added and washed to form the patterns in the microwells. Then, the target bacteria was successfully patterned and captured inside the microwells. The microchip was able to detect bacteria concentrations of $10^{2} \mathrm{CFU} \mathrm{mL}^{-1}$ (Yu et al., 2009).

Luo et al., 2010 developed a nitrocellulose nanofibers surface functionalized with anti-E. coli Abs on the top of silver electrodes Another Ab were coupled with conductive magnetic NPs and incubated with the test sample for target conjugation. After, the purified sample with the conductive label was dispensed on the application pad (a conductometric lateral flow biosensor). After capillary flow equilibrium, the direct-charge transfer between the electrodes was proportional to captured sandwich complex, which could be used to determine the pathogen concentration. The detection time of the biosensor was $8 \mathrm{~min}$, and the detection limit 61 CFU mL-1 (Luo et al., 2010).

A microfluidic device with a portable spectrometer and UV to identify the signal intensity at $375 \mathrm{~nm}$ was developed by Know et al., 2010 and Yoon et al., 2009. The device fabricated by Kwon et al. was constructed in acrylic using an industrial-grade milling machine eliminating the need for photolithography and internal or external pumping. An automatic sampling system was built using drip emitters, such that the system could be connected to a pressurized water pipe for real-time detection of E. coli (Sungkanak et al., 2010). The microdevice developed by Yoon was fabricated by standard soft lithography with the poly(dimethyl siloxane) [PDMS]. A hole was made through the PDMS to make a view cell. Two cover glass slides were bonded to the top and bottom slides of a view cell using oxygen plasma asher. Two inlets and one outlet were then connected to Teflon tubing. A syringe pump was used to inject anti-E. coli conjugated latex particles and E. coli target solutions into the microchannel device (Yoon et al., 2009). Both devices presented $10 \mathrm{CFU} \mathrm{mL}^{-1}$ as detection limit.

A label-free technique based on evanescent wave absorbance changes at $280 \mathrm{~nm}$ from a Ubent optical fiber sensor was reported by Bharadwaj et al. Bending a decladded fiber into a U-shaped structure enhanced the penetration depth of evanescent waves and hence the sensitivity of the probe. A portable optical set-up with a UV Light-Emitting Diode [LED], a spectrometer and U-bent optical fiber probe of $200 \mu \mathrm{m}$ diameter, $0.75 \mathrm{~mm}$ bend radius and effective probe length of $1 \mathrm{~cm}$ demonstrated an ability to detect less than $1000 \mathrm{CFU} \mathrm{mL}-1$ (Bharadwaj et al., 2011).

A method combining immunomagnetic separation and SERS was developed by Guven et al., 2011. Au-coated magnetic spherical NPs were prepared by immobilizing biotin-labeled anti-E. coli Abs onto avidin-coated magnetic NPs and used in the separation and concentration of the E. coli cells. Raman labels have been constructed using rod shaped AuNPs coated with 5,5-dithiobis-(2-nitrobenzoic acid) [DTNB] and subsequently with a 
molecular recognizer. Then DTNB-labeled gold nanorods interacted with the gold-coated magnetic spherical nanoparticle-Ab-E. coli complex. The limit of detection value of this method was $8 \mathrm{CFU} \mathrm{mL}^{-1}$.

The enzyme $\beta$-D-glucuronidase [GUD] is a specific marker for $E$. coli and 4methylumbelliferone- $\beta$-D-glucuronide [MUG] a sensitive substrate for determining the presence of E. coli in a sample. Wildeboer et al., 2010, described a novel hand-held fluorimeter to directly analyse real samples for the presence of $E$. coli. The miniaturized fluorescence detector reduced the incubation time to $30 \mathrm{~min}$ and detect $E$. coli as low as 7 CFU mL-1 in river water samples (Wildeboer et al., 2010).

The use of carbon allotropes like graphene is of a great potential in biosensing due to their extraordinary electrical, physical and optical properties. Huang et al. reported a graphene based biosensor to electrically detect $E$. coli bacteria with high sensitivity and specificity. The device has a graphene film immobilized with Abs against E. coli and a passivation layer. After exposure to $E$. coli bacteria, the graphene device conductance increased significantly.

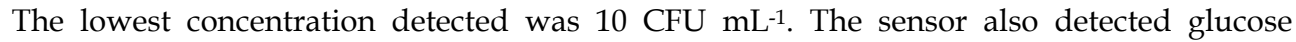
induced metabolic activities of the bound E. coli bacteria in real time (Huang et al., 2011).

Some authors used synthetic materials as recognition materials (Huang et al., 2008; Xue et al., 2009). Xue et al. described a thioglycol acid [TGA] coupled with water-soluble quantum dots as a fluorescence marker for E. coli total count. TGA covalently bound to membrane protein of bacteria cells and after $30 \mathrm{~min}$. fluorescence signal are clean seen at a fluorescent microscope (Xue et al., 2009). Huang et al. also reported a synthetic biosensor with polyurethane [PU] as capture probe of $E$. coli cells and a remote-query magnetoelastic system. The resonance frequency of a liquid immersed magnetoelastic sensor, measured through magnetic field telemetry, changed mainly in response to bacteria adhesion to the sensor and the liquid properties of the culture medium. During its growth and reproduction, E. coli consumed nutrients from a liquid culture medium that decreased the solution viscosity, and, in turn, changed the resonance frequency of the medium-immersed magnetoelastic sensor (Huang et al., 2008).

Cholera is described by WHO as an acute intestinal infection caused by ingestion of food or water contaminated with Vibrio cholerae. It has a short incubation period, from less than one day to five days, and produces an enterotoxin that causes a painless, watery diarrhea that can quickly lead to severe dehydration and death if treatment is not promptly given. Its severity may be confirmed by looking at Haiti recent outbreaks detected after the earthquake. Within 4 days of detecting an unusually high numbers of patients with acute watery diarrhea and dehydration, in some cases leading to death, the National Public Health Laboratory in Haiti isolated Vibrio cholerae serogroup O1, from patients in the affected areas of the earthquake. By March 2011, 4,672 people have died and 252,640 cases had been reported (Centers for Diseases Control and prevention [CDC], 2010). Now, cholera outbreaks are being reported since March 2011 along the Congo River, affecting the Democratic Republic of Congo and the Republic of Congo (WHO, 2011)...

Recently, an ultrasensitive microcantilever-based biosensor with dynamic force microscopy for the detection of Vibrio cholera $\mathrm{O} 1$ with a detection limit of $1 \times 10^{3} \mathrm{CFU} \mathrm{mL}^{-1}$ and a mass sensitivity, $\Delta \mathrm{m} / \Delta \mathrm{F}$, of $146.5 \mathrm{pg} / \mathrm{Hz}$ was reported by Sungkanak et al. 2010. A dry-reagent 
gold nanoparticle-based lateral flow biosensor for the simultaneous detection of Vibrio cholerae serogroups $\mathrm{O} 1$ and $\mathrm{O} 139$, based on immunochromatographic principle, was also developed by (Yu et al., 2011).

Legionella pneumophila [L. pneumophila], which is associated with Pontiac fever and legionnaires disease, is commonly found in air conditioning and refrigerating towers, but can also be transported in drinking and freshwaters (Ashbolt, 2004). The detection of $L$. pneumophila in water samples using standard microbiological culture techniques is a delayed process because the bacterium is slow-growing and nutritionally fastidious, to the point that other species may compete with Legionella even when antibiotic are supplemented (Cooper et al., 2009).

Miranda-Castro et al. described an electrochemical sensing method for semiquantitative evaluation of L. pneumophila (Miranda-Castro et al., 2009). The DNA fragments were amplified by PCR and hybridized to a biotin-labeled reporter sequence and then to a thiolated stem-loop structure immobilized onto gold electrodes as a reporter molecule with 1-naphthyl phosphate as a substrate. 1-Naphthol enzymatically generated was determined by differential pulse voltammetry [DPV].

An immnuosensor using side-polished fiber based on SPR with halogens and LED light source (850 nm LED) for the detection of L. pneumophila was reported by (Lin et al., 2007). The SPR curve on the optical spectrum described on the optical spectrum analyzer [OSA] demonstrated a width wavelength of sensing range of SPR effects and sensitive responses. The detection limit was $10^{1} \mathrm{CFU} \mathrm{mL}-1$ and the detection range of $10^{1}$ to $10^{3} \mathrm{CFU} \mathrm{mL}^{-1}$ (Lin et al., 2007).

Optical Waveguide Lightmode Spectroscopy [OWLS] technique uses the evanescent field of a He-Ne laser which is coupled into a planar waveguide via an optical grating (Vörös et al., 2002). An OWLS real-time analytical system for the detection of L. pneumophila was described by Cooper et al.. An aqueous suspension of L. pneumophila was passed across the surface of waveguides functionalized with a specific anti-Legionella antibody. The binding between the bacterial cells and the Ab specific for that cell resulted in an increase in the refractive indices of the transverse electric and transverse magnetic photoelectric currents. The assay is presented as a rapid $\left(25 \mathrm{~min}\right.$.) and sensitive $\left(1.3 \times 10^{4} \mathrm{CFU} \mathrm{mL}-1\right)$ detection method for L. pneumophila contamination in water samples (Cooper et al., 2009).

Regularly, water is contaminated with more than one pathogen, so the development of multi-analyte arrays are quiet relevant. Wolter et al. and Karsunke et al. reported a chemiluminescence microarray for the simultaneous detection of E. coli, Salmonella typhimurium and L. pneumophila in waters (Karsunke et al., 2009; Wolter et al., 2008).

The immuno-microarray described by Wolter et al. were produced on PEG-modified glass substrates by means of a contact arrayer. The chemiluminescence reaction was accomplished by a streptavidin-horseradish peroxidase catalyzed reaction of luminol and hydrogen peroxide, and was recorded by a sensitive charge coupled device [CCD] camera. The detection limits, in multianalyte experiments, achieved in 13 minutes, were $3 \times 10^{6}$ cells $\mathrm{mL}^{-1}$, $1 \times 10^{5}$ cells $\mathrm{mL}^{-1}$, and $3 \times 10^{3}$ cells $\mathrm{mL}^{-1}$ for S. typhimurium, L. pneumophila, and E. coli O157:H7, respectively (Wolter et al., 2008). 
Zhou et al. reported the development of a DNA microarray for detection and identification of L. pneumophila and ten other pathogens like Salmonella spp., Leptospira interrogans and Vibrio Cholera, in drinking water. The combined two-step enrichment procedure allows detection sensitivity of $0.1 \mathrm{ng}$ DNA or $10^{4} \mathrm{CFU} \mathrm{mL}-1$ achieved for pure cultures of each target organism (Zhou et al., 2011).

Salmonella is related with water and food-borne severe diarrhea. It contaminates more often dairy products from poultry but because these pathogens can be present in animal faeces water resources can as well be contaminated (Karsunke et al., 2009; Nayak et al., 2009; Wolter et al., 2008; Zhou et al., 2011).

Guntupalli et al. developed a magnetoelastic biosensor for S. typhimurium in a mixed microbial population. A varying magnetic field was applied to magnetoelastic particles coated with an $\mathrm{Au} / \mathrm{Chromium}[\mathrm{Cr}]$ thin film and a specific $\mathrm{Ab}$ in contact with the analyte and the resulting signal was measured. A detection limit of $5 \times 10^{3} \mathrm{CFU} \mathrm{mL}-1$ and the sensitivity of $139 \mathrm{~Hz}$ decade $^{-1}$ were observed for a $2 \times 0.4 \times 0.015 \mathrm{~mm}$ sensor (Guntupalli et al., 2007).

About 90 species of Mycobacteria have been found, 20 of which are known to cause disease in humans. Among these, M. avium, M. intracellulare, M. chelonae, M. kansasii, M. marinum, M. fortuituma and M. ulcerans are considered potential human pathogens. These are called Nontuberculosis mycobacteria [NTM] and have been identified in numerous environmental sources, including water. NTM species have been isolated from water sources as well as waste water, surface water, recreational water, ground water and tap water. In this field, there are some recent advances in the development of fast-screening method to detect Mycobacteria. Hunter et al. published a research report about treatment, distribution, standard methods isolation, comparison of culture media and analysis in water (Hunter et al., 2001). Most recent developments in these area report PCR-based detection methods (Jing et al., 2007; Tobler et al., 2006), and demand new emerging biosensing technology.

Recent efforts for detecting whole bacterial communities have been made in order to detect possible bacterial pathogens which are not included in the standard monitoring processes (Hong et al., 2010; Kormas et al., 2010; Poitelon et al., 2010; Revetta et al., 2010). The analysis of bacterial 16S rRNA gene diversity in drinking water distribution systems [WDS] can indicate the presence of Proteobacteria even after the chlorine disinfection treatment (Revetta, 2010).

Poitelon and coworkers presented the variations of $16 \mathrm{~S}$ rDNA phylotypes prior and after chlorination treatments in 2 WDS in France. The 16S rDNA sequences were grouped into operational taxonomic units [OTUs] standards and acquired for each sample. Significant differences were found in terms of structure and composition of the bacterial community before and after the chlorination disinfection. The predominant bacteria found were alphaand betaproteobacteria (Poitelon et al., 2010). Kormas, 2010, also presented a similar study in the WDS of Trikala city, Greece. This work showed a possible microbiological risk, not from microorganisms that are routinely monitoring, but from Mycobacteria-like Bacteria.

Overall, the wiseness of the ecology of the bacterial communities in the WDS is important to be acquainted with the chlorination resistance of pathogen in these microbiological communities (Kormas et al., 2010). 


\section{Cyanobacteria and algae biosensors}

The toxic metabolites produced by Cyanobacteria in surface waters are another potential threat to drinking water. This has been recognized recently after detecting cyanobacterial toxins [cyanotoxins] in a great number of water samples, from nearly every region on earth. Outbreaks of human poisoning attributed to toxic Cyanobacteria have been reported, following exposure of individuals to contaminated water, while drinking, swimming and canoeing (WHO, 1999).

Cyanotoxins [CNs] belong to rather diverse groups of chemical substances each of which shows specific toxic mechanisms in vertebrates. Some CNs are strong neurotoxins (anatoxina, saxitoxins), others are primarily toxic to the liver (microcystins, nodularin and cylindrospermopsin), and yet others (such as the lipopolysaccharides) appear to cause gastroenteritis (WHO, 1999). Microcystins [MCs] are geographically the most widely CNs distributed in freshwaters. MCs are peptide toxins produced by Cyanobacteria populations in high proportions, a typical symptom of eutrophication. Microcystin-LR [MC-LR] is the most typical element of this group and seems to display severe hepatotoxic and carcinogenic activity. MC-LR concentration in waters for human consumption is regulated by environmental Protection Agency [EPA], EU and WHO, who recommended a limit of $1 \mu \mathrm{g}$ $\mathrm{L}^{-1}$ MC-LR in drinking waters (EC, 2000, 2006; WHO, 1999). Current standard methods to monitor MC-LR require sophisticated and expensive procedures and specific laboratorial conditions that take long time to reach the intend result. Within that time the contamination can move/spread out, while users of recreational waters and possible consumers are at risk of contracting serious infections.

A huge number of novel methods and techniques have been developed recently for this purpose. They are presented in table 2 (Almeida et al., 2006; Allum et al., 2008; Campàs et al., 2007; Campàs \& Marty, 2007; Dawan et al., 2011; Ding \& Mutharasan, 2010; Gregora \& Marsálek, 2005; Hu et al., 2008; Lindner et al., 2009; Long et al., 2009, 2010; Loypraseta et al., 2008; Pyo et al., 2005, 2006; Pyo \& Jin, 2007; Queirós et al., 2011; Sheng et al., 2007; Wang et al., 2009; Xia et al., 2010, 2011; Zhang et al., 2007). Optical immuno-based techniques are by large the most widely techniques that have been developed for the detection of MCs (Campàs et al., 2007; Hu et al., 2008; Long et al., 2010; Loypraseta et al., 2008; Pyo et al., 2005, 2006; Pyo \& Jin, 2007; Sheng et al., 2007; Xia et al., 2010).

The chemiluminescence sensing technique used in microbial biosensors relies on the generation of electromagnetic radiation as light by the release of energy from a chemical reaction using synthetic compounds (highly oxidized species) which respond to the target analyte in a dose-dependent manner (Hu et al., 2008; Lindner et al., 2009; Su et al., 2011). Lindner et al. reported a rapid immunoassay for sensitive detection of MC-LR using a portable chemiluminescence multichannel immunosensor. The sensor device is based on a capillary ELISA technique in combination with a miniaturized fluidics system and uses chemiluminescence as the detection principle. Minimum concentrations of $0.2 \mu \mathrm{g} \mathrm{L}^{-1} \mathrm{MC}$-LR could be measured in spiked buffer as well as in spiked water samples (Wang et al., 2009). $\mathrm{Hu}$ et al. also presented a chemiluminescence immunosensor based on gold nanoparticles. The immunoassay included three main steps: indirect competitive immunoreaction, oxidative dissolution of AuNPs, and indirect determination for MCs with $\mathrm{Au}^{3+}$-catalysed luminol chemiluminesent system. The method has an extensive working range of $0.05-10 \mu \mathrm{g}$ $\mathrm{L}^{-1}$, and a limit of detection of $0.024 \mu \mathrm{g} \mathrm{L}^{-1}$ (Hu et al., 2008). 
Evanescent wave fiber optic immunosensors have been developed to determine numerous target compounds based on the principle of immunoreaction and total internal reflect fluorescent. They also show potential advantages such as miniaturization, sensitivity, costeffectiveness, and capability of real-time rapid measurements (Long et al., 2009). A portable trace organic pollutant analyzer based on the principle of immunoassay and total internal reflection fluorescence was developed by Long et al.. The reusable fiber optic probe surface was produced by covalently immobilizing a MC-LR-ovalbumin conjugate onto a selfassembled thiol-silane monolayer of fiber optic probe through a heterobifunctional reagent. The recovery of MC-LR added to water samples at different concentrations ranged from 80 to $110 \%$ with relative standard deviation values less than $5 \%$ (Long et al., 2009).

Pyo et al. developed a few number of optical immuno-based assays to detect MC-LR: a gold colloidal immunochromatographic strip, a fluorescence immunochromatographic strip and cartridge and a PDMS microchip using a liquid-cord waveguide as optical detectors and a MAb against MC-LR as recognition element. The detection limits found were $0.05 \mu \mathrm{g} \mathrm{L} \mathrm{L}^{-1}$, $0.15 \mu \mathrm{g} \mathrm{L}^{-1}$ and $0.05 \mu \mathrm{g} \mathrm{L}^{-1}$, respectively (Pyo et al., 2005, 2006; Pyo \& Jin, 2007).

Optical sensing techniques, and specially integrated in immunoarrays, are particularly powerful tools in high throughput screening to monitoring multiple analytes simultaneously (Long et al., 2010; Su et al., 2011). Long et al. developed an optical fiberbased immunoarray biosensor for the detection of multiple small analytes (MC-LR and trinitroluene [TNT]). These compounds can be detected simultaneously and specifically within an analysis time of about $10 \mathrm{~min}$ for each assay cycle. The limit of detection for MCLR was $0.04 \mu \mathrm{g} \mathrm{L}-1$. This compact and portable immunoarray shows good regeneration performance and binding properties, robustness of the sensor surface and accuracy in the measurement of small analytes which can be considered an excellent multiple assay platform for clinical and environmental samples (Long et al., 2010).

A suitable disposable type biosensor for on-site monitoring of MC-LR in environmental waters was described by Zhang et al.. They reported a competitive binding non-separation electrochemical enzyme immunoassay, using a double-sided microporous gold electrode in cartridge-type cells. Mean recovery of MC-LR added to tap water was $93.5 \%$, with a coefficient of variation of $6.6 \%$ (Zhang et al., 2007).

Electrochemical detection methods are also commonly used (Campàs et al., 2007; Campàs \& Marty, 2007; Dawan et al., 2011; Loypraseta et al., 2008; Pyo \& Jin, 2007, Wang et al., 2009; Zhang et al., 2007).

Campàs et al. developed a highly sensitive using both MAb and Polyclonal $\mathrm{Ab}$ [PAb] against MC-LR. This amperometric immunosensor was compared with colorimetric immunoassay, PP inhibition assay and High Performance Liquid Chromatography [HPLC]. The amperometric immunosensor simplifies the analysis, and offer faster and cheaper procedures than others assays.

Wang et al. described a simple, rapid, sensitive, and versatile ELISA-SWNT-paper based sensor for detection of MC-LR in waters. This paper described the use of paper saturated with SWNT embebed in a poly(sodium 4-styrenesulfonate) solution where the Abs are after immobilized. The chronoamperometric detection system was tested and performed a LOD of $0.6 \mu \mathrm{g} \mathrm{L} \mathrm{L}^{-1}$ with a linear range up to $10 \mu \mathrm{g} \mathrm{L}-1$ (Wang et al., 2009). 


\begin{tabular}{|c|c|c|c|c|c|}
\hline \multicolumn{2}{|c|}{ Methods } & \multirow{2}{*}{ Microcystins } & \multirow{2}{*}{ LOD $\left.\mu g^{1} L\right)^{1}$} & \multirow{2}{*}{$\begin{array}{l}\text { Detection range } \\
\qquad\left(\mu \mathrm{g}^{-1} \mathrm{~L}^{-1}\right.\end{array}$} & \multirow{2}{*}{ References } \\
\hline Capture & Transduction & & & & \\
\hline Immunological & Electrochemical & $-\mathrm{LR}$ & 0.6 & up to 10 & Wang. et al., 2009 \\
\hline Immunological & Optical & $-L R$ & 0.03 & $0.1-10$ & Long et al., 2009 \\
\hline Immunological & Optical & $\begin{array}{l}-\mathrm{LR} \\
-\mathrm{RR}\end{array}$ & down to 0.1 & $0.001-30$ & Sheng et al., 2007 \\
\hline Immunological & Piezoelectric & $-\mathrm{LR}$ & $\begin{array}{c}0.1 \text { (river) } \\
1.00 \mathrm{E}^{3} \text { (tap) }\end{array}$ & $1-100$ & $\begin{array}{c}\text { Ding \& Mutharasan, } \\
2010\end{array}$ \\
\hline Immunological & Optical & Any & 0.024 & $0.05-10$ & Hu et al., 2008 \\
\hline Molecular Imprinting & Optical & -LR & 0.3 & $0.3-1.4$ & Queirós et al., 2011 \\
\hline Enzimatic & Optical & -LR & $1.00 \mathrm{E}-02$ & $0-100$ & Almeida et al., 2006 \\
\hline Immunological & Optical & $-\mathrm{LR}$ & $1.50 \mathrm{E}-01$ & $0.150-1.6$ & Pyo \& Jin, 2007 \\
\hline Immunological & Electrochemical & $-L R$ & $\begin{array}{r}0.10(\mathrm{MAb}) \\
(\mathrm{PAb})\end{array}$ & $\begin{array}{l}10^{-4}-10^{2} \text { (MAb) } \\
10^{21}-10^{2}(\mathrm{PAb})\end{array}$ & Campàs \& Marty, 2007 \\
\hline Immunological & Mechanical & $-L R$ & 1 & $1-1000$ & Xia et al., 2011 \\
\hline Enzimatic & Optical & -LR & 1 & $0-1000$ & Allum et al., 2008 \\
\hline Immunological & Optical & $-\mathrm{LR}$ & 0.2 & $0-10$ & Lindner et al., 2009 \\
\hline Enzimatic & $\begin{array}{l}\text { Electrochemical } \\
\text { Optical }\end{array}$ & Any & $\begin{array}{c}37 \text { (Electrochemical) } \\
\text { (Optical) }\end{array}$ & $\begin{array}{c}2 \text { 37-188 (Electrochemical) } \\
\text { - (Optical) }\end{array}$ & Campàs et al., 2007 \\
\hline Immunological & Electrochemical & $-\mathrm{LR}$ & 0.1 & $0.01-3.16$ & Zhang et al., 2007 \\
\hline Immunological & Electrochemical & $-\mathrm{LR}$ & $7.00 \mathrm{E}-06$ & $10 E^{6}-1$ & Loypraserta et al., 2008 \\
\hline Immunological & Optical & $-\mathrm{LR}$ & 1 & $1-100$ & Xia et al., 2010 \\
\hline Immunological & Optical & $-\mathrm{LR}$ & 0.05 & $0.05-1.2$ & Pyo et al., 2005 \\
\hline Immunological & Optical & $-\mathrm{LR}$ & 0.05 & $0-1.6$ & Pyo et al., 2006 \\
\hline Immunological & Optical & -LR & 0.04 & $0-1000$ & Long et al., 2010 \\
\hline Immunological & Electrochemical & $-\mathrm{LR}$ & $1.00 \mathrm{E}-06$ & $1.00 \mathrm{E}^{6}-1.00 \mathrm{E}^{4}$ & Dawan et al., 2011 \\
\hline
\end{tabular}

LOD - Limit Of Detection; WE - With Enrichment; WOE - WithOut Enrichment.

Table 2. Emerging techniques for the detection of microcystins in waters.

The use of electrochemical capacitance systems as detection methods in biosensors allows obtaining exceptionally low limits of detection. Loypraserta et al. and Dawan et al. described a label-free immunosensor based on a modified gold electrode incorporated with AgNPs to enhance the capacitive response to MC-LR has been developed. Anti-MC-LR was immobilized on AgNPs bound to a self-assembled thiourea monolayer, and compared with a bare electrode without the modified AgNPs (Dawan et al., 2011; Loypraseta et al., 2008). MC-LR could be determined with a detection limit of 7.0 and $1.0 \mu \mathrm{g} \mathrm{L}^{-1}$ for (Loypraseta et al., 2008) and (Dawan et al., 2011), respectively. Compared with the modified electrode without AgNPs, this assay presented higher sensitivity and lower limit of detection.

The Adda (3-amino-9-methoxy-2,6,8-trimethyl-10-phenyldeca-4,6-dienoic acid) group of MCs is responsible by the infiltration of toxins in the liver cells where MCs irreversibly bind to serine/threonine protein phosphatases type 2A [PP2A] and type 1 [PP1], inhibiting their 
enzymatic activity (Almeida et al., 2006; Campàs et al., 2007). These enzymes are involved on the dephosphorylation of proteins. Consequently, their inhibition results in hyperphosphorylation and reorganisation of the microfilaments, promoting tumours and liver cancer (Almeida et al., 2006; Campàs et al., 2007). Almeida et al., Allum et al. and Campàs et al. developed enzymatic-based capture probes based on PP1 and PP2A inhibition. Almeida et al. and Allum et al. presented a simple, rapid and reproducible PP1 inhibition colorimetric test, with the first one presenting a detection limit of $1.00 \mathrm{E}^{-2} \mu \mathrm{g} \mathrm{L}^{-1}$. Allum et al. showed an optical fluorometric biosensor based on protein phosphate for the detection of MC-LR or diarrhetic shellfish toxins. The immobilised format described was used to evaluate the potential to translate protein phosphate into a prototype biosensor suitable as a regulatory assay allowing faster throughput than a solution assay and in particular, in assessments of sensitivity and reusability (Allum et al., 2008).

A chronoamperometric biosensor was developed by Campàs et al. 2007 also based on the inhibition of the PP2A. The enzyme was immobilized by the use of poly(vinyl alcohol) azide-unit pendant water-soluble photopolymer. The standard inhibition curve has provided a $50 \%$ inhibition coefficient [IC50] of $83 \mu \mathrm{g} \mathrm{L}^{-1}$, which corresponds to a limit of detection of $37 \mu \mathrm{g} \mathrm{L}^{-1}$ (35\% inhibition). Real samples were analysed using the developed amperometric biosensor and compared to those obtained by a conventional colorimetric protein phosphatase inhibition [PPI] assay and HPLC. The results demonstrated that the developed amperometric biosensor may be used as screening method for MCs detection (Campàs et al., 2007).

A dendritic surfactant for MC-LR detection by double amplification in a QCM biosensor was presented by Xia et al.. For primary amplification, an innovative interface on the QCM was obtained as a matrix by the vesicle layer formed by a synthetic dendritic surfactant. The vesicle matrix was functionalized by a MAb against MC-LR to detect the analyte. The results showed that a detection limit of $100 \mu \mathrm{g} \mathrm{L}-1$ was achieved by the first amplification. A secondary amplification was implemented with anti-MC-LR AuNPs conjugates as probes, which lowered the detection limit for MC-LR to $1 \mu \mathrm{g} \mathrm{L}-1$ (Xia et al., 2011).

A piezoelectric-excited millimeter-sized cantilever sensor was developed by Ding et al. for the sensitive detection of MC-LR in a flow format using MAb and PAb that bind specifically to MC-LR. Monoclonal antibody against MC-LR was immobilized on the sensor surface via amine coupling. As the toxin in the sample water bound to the antibody, resonant frequency decreased proportional to toxin concentration. Positive verification of MC-LR detection was confirmed by a sandwich binding on the sensor with a second antibody binding to MC-LR on the sensor which caused a further resonant frequency decrease (Ding \&_Mutharasan, 2010).

Very recently, Queirós et al. described a completely new approach a Fabry-Pérot sensing probe based on an optical fibre tip coated with a MC-LR selective thin film. The membranes were developed by molecular imprinting of MC-LR in a sol-gel matrix that was applied over the tip of the fibre. The sensor showed low thermal effect, thus avoiding the need of temperature control in field applications. It presented a detection limit of $0.3 \mu \mathrm{g} \mathrm{L}^{-1}$ and shows excellent selectivity for MC-LR against other species co-existing with the analyte in environmental waters (Queirós et al., 2011). 
Saxitoxins were originally isolated from shellfish where they are concentrated from marine dinoflagellates and are one of the causative agents of paralytic shellfish poisoning [PSP] and have caused deaths in humans (Haughey et al., 2011; WHO, 1999; Yakes et al., 2011).

Saxitoxins have been found in the cyanobacteria Aphanizomenon flos-aquae, Anabaena circinalis, Lyngbya wollei and Cylindrospermopsis raciborskii. Saxitoxins have been found in some countries in diverse cyanobacteria genera, such as Aphanizomenon flos-aquae strains NH-1 and NH-5 in North America, C1 and C2 toxins from Anabaena circinalis strains in Australia and Cylindrospermopsis raciborskii in Brazil (WHO, 1999).

Institute of Agri-Food and Land Use, the US Food and Drug Administration, and the Joint Institute for Food Safety and Applied Nutrition recently reported several SPR platforms biosensor based on inhibition assays to detect PSP toxins (Haughey et al., 2011; Yakes et al., 2011). A saxitoxin PAb (R895) and a MAb (GT13A) were tested and compared. MAb GT13A shows a higher sensitivity $77.8 \%-100 \%$ and was then immobilized into the SPR biosensor surface. The final system provides rapid substrate formation, about $18 \mathrm{~h}$ for saxitoxin conjugation with low reagent consumption, contains a reference channel for each assay, and is capable of triplicate measurements in a single run with detection limits well below the regulatory action level (Haughey et al., 2011; Yakes et al., 2011).

Other biosensors were developed for detection of other toxic algae, beyond cyanobacteria, present in environmental waters. Orozco et al. described an electrochemical DNA-based sensor device for detecting toxic algae (Prymnesium paroum, and Gymnodinium catenatum). A sandwich hybridization assay was developed with a thiol (biotin) labelled capture probe immobilized onto gold or carbon electrodes, the synthetic DNA was applied to the sensor and allowed to hybridize to the capture probe. A signal probe with HRP label was then applied, followed by an antibody to the HRP and a substrate. The electrical signal obtained from the redox reaction was proportional to the amount of DNA applied to the biosensor (Orozco et al., 2011; Orozco \& Medlin, 2011).

Diercks-Horn et al. reported very recently the ALGADEC device which is a semiautomated ribosomal RNA [rRNA] biosensor for the detection of Alexandrium minutum toxic algae. The biosensor consisted of a multiprobe chip with an array of 16 gold electrodes for the detection of up to 14 target species. The multiprobe chip was placed inside an automated hybridization chamber, which was in turn placed inside a portable waterproof case with reservoirs for different reagents. The device processed automatically the main steps of the analysis and completed the electrochemical detection of toxic algae in less than $2 \mathrm{~h}$ (Diercks-Horn et al., 2011). Furthermore, Diercks et al. reported a colorimetric sandwich hybridization in a microtiter plate assay also for the detection of Alexandrium minutum. The system is an adaptation of a commercially available PCR ELISA Dig Detection Kit to be possible the rapid assessment of specificity of the two probes. The mean concentration of RNA per cell of was determined to be $0.028 \mathrm{ng} \pm 0.003$ (Diercks et al., 2008).

Metfies et al. described an electrochemical DNA-biosensor for the detection of the toxic dinoflagellate Alexandrium ostenfeldii (Metfies et al., 2005). This device is similar to the one reported by Diercks-Horn et al. very recently. 


\section{Fungi biosensors}

The knowledge-based concerning the occurrence of fungi in water is low. Fungal contamination of water has been reported for decades, although investigations have been inadequate compared with those of bacteria. Fungi are responsible by infections, allergic reactions and production of toxins [mycotoxins]. Mycotoxins contaminate food and drinks with harsh effects on human and animal health, including cancer, immunological effects and death (Russell et al., 2005). Water, either drinking or nondrinking, may be an effective medium for toxin and biological weapon dispersal. In nondrinking water, the toxin could be spread, from a shower and then inhaled. Workplaces such as farms or car washes where high volumes of water are employed could be susceptible to toxins or fungi. Furthermore, drinking water for animals may be at a considerably higher level of risk than that for humans, thereby increasing the threat to food sources (Russell et al., 2010).

Russell and Paterson proved the production of the mycotoxin zearalenone [ZEN] in drinking waters by Fusarium graminearum (Russell \& Paterson, 2007). ZEN was purified with an immunoaffinity column and quantified by HPLC with fluorescence detection. The extracellular bear of ZEN was $15.0 \mathrm{ng} \mathrm{L}^{-1}$ (Russell et al., 2005; Russell \& Paterson, 2007).

Aflatoxins, from Aspergillus flavus, were detected from a cold water storage tank and first reported as the first reported natural occurrence of any mycotoxin in waters (Paterson et al., 1997). Very recently Kattke et al. reported a FRET-based quantum dot immunoassay for rapid and sensitive detection of Aspergillus amstelodami (Kattke et al., 2011). The biosensor complex is formed when a quencher-labeled analyte is bound by the antigen-binding site of the quantum dot-conjugated antibody; when excited, the quantum dot will transfer its energy through FRET to the quencher molecules due to their close proximity. With the addition of the target analytes the quencher-labeled analytes dislocation causes disruption of FRET, which translates to increased quantum dot donor emission signal. The optimized displacement immunoassay detected A. amstelodami concentrations as low as $10^{3}$ spores $\mathrm{mL}^{-1}$ in less than five minutes (Kattke et al., 2011).

Few biosensors for the rapid detection of different mycotoxins in food and beverages samples with special focus to electrochemical detection methods (Alonso-Lomillo et al., 2010; Dinçkaya et al., 2011; S. Li et al., 2011) and enzymes as capture probes (Alonso-Lomillo et al., 2010; S. Li et al., 2011) have been developed recently.

Li et al. presented an amperometric aflatoxin B1 biosensor developed by aflatoxin-oxidase [AFO], embedded in sol-gel, linked to MWCNTs-modified platinum [Pt] electrode (Li et al., 2011B). A DNA-based gold nanoparticles biosensor was developed for detection of aflatoxin M1. A self-assembled monolayer of cysteamine and gold nanoparticles on the SAM were prepared on gold electrodes, layer-by-layer. The assembly processes of cysteamine, gold nanoparticles, and ss-HSDNA were monitored with the help of electrochemical impedance spectroscopy [EIS] and cyclic voltammetry [CV] techniques. The biosensor provided a linear response to aflatoxin M1 over the concentration range of 1-14 $\mathrm{ng} \mathrm{mL^{-1 }}$ with a standard deviation of $\pm 0.36 \mathrm{ng} \mathrm{mL}^{-1}$ (Dinçkaya et al., 2011).

Biosensors for the rapid detection of Ochratoxin [Ochra] were also described. Ochra is a group of mycotoxins produced as secondary metabolites by fungi which presents a serious hazard to human and animal health (Metfies et al., 2005; Russell et al., 2010; Yuan et al., 2009). 
A sensitive enzyme-biosensor based on screen-printed electrodes was presented by AlonsoLomillo et al., 2010. A competitive immunoassay with optical detection (SPR using AuNPs) was described by Yuan et al., in whom a mixed self-assembled monolayer was arranged with the immobilization of Ochra through its ovalbumin conjugated with a polyethylene glycol linker (Yuan et al., 2009).

Sapsford et al. reported an array biosensor for the detection of multiple mycotoxins such as ochratoxin A, fumonisin B, aflatoxin B1 and deoxynivalenol in food or beverages. The arrangement of the test was a competitive-based immunoassay, using monoclonal antibodies and the simultaneous detection was performed in less than 15 minutes (Sapsford et al., 2006).

\section{Protozoa biosensors}

Further on, it is estimated that 2.5 million cases of world annual illness outcome from food and water parasites. Four parasites, Cryptosporidium parvum, Cyclosporacayetanensis, Giardia lamblia and Toxoplasma gondii, account for the majority of cases, with $71 \%$ of waterborne diseases caused by G. lamblia and Cryptosporidium (Ashbolt, 2004; Rasooly \& Herold, 2006; Smith \& Nichols, 2010).

Frequent methods for protozoa detection are PCR-based assays (Loge et al., 2002; Toze, 1999) and more recently immunomagnetic separation and fluorescent assays (Ferrari et al., 2006; Mons et al., 2009). These techniques are used to evaluate the microbiological quality of water, and to assess the efficiency of pathogen removal in drinking and wastewater treatment plants (Girones et al., 2010).

Li et al., 2011B, reported a most likely biosensor approached for the detection of G. lamblia cysts based on the catalytic growth of AuNPs (X.X. Li et al., 2009). The assay can be described in 7 steps. First the sample is transferred and secondly concentrated; the third step is the incubation of the AuNPs immobilized with a MAb against G. lamblia as capture probe, the free gold probes are separated and the sample are resuspended and left growing; the seventh step is the detection by UV-VIS. Detection limit of G. lamblia cysts was determined as low as $1.088 \times 10^{3}$ cells $\mathrm{ml}^{-1}$ (X.X. Li et al., 2009).

\section{Conclusion}

Although WHO considers H5N1 water contamination an emerging issue, with high potential risks of infection, it seems that most issued waterborne viruses include EV. The toxic metabolites produced by Cyanobacteria in surface waters are another potential threat to drinking water, being MC-LR widely studied and target of biosensing development. Despite the low occurrence of fungi in water, mycotoxins have been also reported and target of biosensing technology. Bacteria are definitely the major pathogenic specie responsible for water-borne disease. They are mostly from faecal source. E. coli has been assayed thoroughly by immunological and nucleic acid methods, coupled to electrochemical or optical detection methods. Protozoa can be $0.01 \mathrm{~mm}$ to $1.0 \mathrm{~mm}$ in length and are quite easy to identify, turning out biosensors less desired. They are much less reported and detected mostly by PCR-based assays, which are used to evaluate the microbiological quality of water. 
The biosensor schemes for detection of pathogens in waters presented in this chapter are only a few of many emerging devices and assays that are being developed for several applications. Biosensors offer high sensitivity and specificity, allowing the detection of extremely low infection doses and multiple target analyte at once. The integration of several sensors in networks providing multi-analyte detection and their portability of these sensor networks are at the forefront. This allows the fast screening and the prevention of outbreaks and its consequences.

The future directions of the use of biosensors in environmental contaminant analysis may lead to the combination of these sensor networks with wireless signal transmitters for remote sensing at real-time monitoring. Low manufacturing and production costs are also attractive features that may lead the market expansion in a very short time. They are indeed promising tools for field detection and fast screening of pathogens in waters...

\section{Nomenclature}

$\begin{array}{ll}\text { Ab } & \text { Antibody } \\ \text { Abs } & \text { Antibodies } \\ \text { Adda } & \text { 3-amino-9-methoxy-2,6,8-trimethyl-10-phenyldeca-4,6-dienoic acid } \\ \text { AFM } & \text { Atomic Force Microscopy } \\ \text { AFO } & \text { Aflatoxin-oxidase } \\ \text { Ag } & \text { Silver } \\ \text { AgNPs } & \text { Silver NanoParticles } \\ \text { AIV } & \text { Avian Influenza Virus } \\ \text { AOM } & \text { Aluminium Oxide Membrane } \\ \text { ATR } & \text { Attenuated Total Reflectance } \\ \text { Au } & \text { Gold } \\ \text { BTV } & \text { BlueTongue Virus } \\ \text { CCD } & \text { Charge Coupled Device } \\ \text { CFU } & \text { Colony Form Unit } \\ \text { CNs } & \text { Cyanotoxins } \\ \text { Cr } & \text { Chromium } \\ \text { CV } & \text { Cyclic Voltammetry } \\ \text { DNA } & \text { DeoxyriboNucleic Acid } \\ \text { DPV } & \text { Differential Pulse Voltammetry } \\ \text { DTNB } & \text { 5,5-dithiobis-(2-nitrobenzoic acid) } \\ \text { E. Coli } & \text { Escherichia coli } \\ \text { EIS } & \text { Electrochemical Impedance Spectroscopy } \\ \text { ELISA } & \text { Enzyme-Linked ImmunoSorbant Assay } \\ \text { EPA } & \text { Environmental Protection Agency } \\ \text { EPEC } & \text { EnteroPathogenic Escherichia coli } \\ \text { EU } & \text { European Union } \\ \text { EV } & \text { Enteric Viruses } \\ \text { FETs } & \text { Field Effect Transistors } \\ \text { FRET } & \text { Fluorescence Resonance Energy Transfer } \\ \text { GUD } & \text { b-D-glucuronidase } \\ \text { HBV } & \text { Hepatitis B Virus } \\ & \end{array}$


HPAI Highly Pathogenic Avian Influenza

HPLC High Performance Liquid Chromatography

HRP HorseRadish Peroxidase

IC50 half maximal Inhibitory Concentration

IR Infra-Red

ITO Indium tin oxide

LED Light-Emitting Diode

LOD Limit Of Detection

$\mathrm{MAb} \quad$ Monoclonal Antibody

MC-LR Microcystin-LR

MCs Microcystins

MOS Metal Oxide Semiconductor

MUB

MWNT

NMR

NPs

NTB

NWs

Ochra

4-methylumbelliferone-b-D-glucuronide

Multi-Walled carbon NanoTubes

Nuclear Magnetic Ressonance

Nanoparticles

Non-Tuberculosis Mycobacteria

OSA

OWLS

$\mathrm{PAb}$

PCR

PEG

Pfu

PMDS

NanoWires

Ochratoxin

PP

Optical Spectrum Analyzer

Optical Waveguide Lightmode Spectroscopy

Polyclonal Antibody

Polymerase Chain Reaction

Poly(ethylene glycol)

Pock-forming units

PP1

Polydimethylsiloxane

PolyPyrrole

Protein Phosphatase 1

PP2A

Protein Phosphatase 2A

PPI

Protein Phosphatase Inhibition

PPNWs

PolyPyrrole NanoWires

PQC

PSP

$\mathrm{Pt}$

Piezoelectric Quartz Crystal

Paralytic Shellfish Poisoning

PU

Platinum

QCM

RNA

Polyurethane

rRNA

Quartz Crystal Microbalance

RT-PCR

RiboNucleic Acid

ribosomal RNA

SAW

Reverse Transcriptase - Polymerase Chain Reaction

SERS

Surface Acoustic Wave

SPR

$\mathrm{SpV}$

SWNT

TGA

TNT

Surface Enhanced Raman Scattering

Surface Plasmon Resonance

Smallpox Virus

Single-Wall NanoTube

Thioglycol Acid

UV

Trinitroluene

Ultra-Violet 
$\mathrm{Vis}$

WHO

WISE

ZEN
Visible

World Health Organization

Water Information System for Europe

Zearalenone

\section{References}

Allum, L.L., Mountfort, D.O., Gooneratne, R., Pasco, N., Goussaind G., \& Halle, E.A.H. (2008). Assessment of protein phosphatase in a re-usable rapid assay format in detecting microcystins and okadaic acid as a precursor to biosensor development. Toxicon 52 (7), pp. 745-753.

Almeida, V., Cogo, K., Tsai, S.M., \& Moon, D.H. (2006). Colorimetric test for the monitoring of microcystins in Cyanobacterial culture and environmental samples from southeast - Brazil. Brazilian Journal of Microbiology 37, pp. 192-198.

Alonso-Lomillo, M.A., Domínguez-Renedo, O., Ferreira-Gonçalves L., \& Arcos-Martíneza, M.J. (2010). Sensitive enzyme-biosensor based on screen-printed electrodes for Ochratoxin A. Biosensors and Bioelectronics 25 (6), pp. 1333-1337.

An, J., \& Carmichael, W.W. (1994). Use of colorimetric protein phosphatase inhition assay and enzime linked immunosorbent assay for the study of microcystins and nodularin. Toxicon 32, pp. 1495-1507.

Ashbolt, N.J. (2004). Microbial contamination of drinking water and disease outcomes in developing regions. Toxicology 198, pp. 229-238.

Bao, P.-D., Huang, T.-Q., Liu, X.-M., \& Wu, T.-Q. (2001). Surface-enhanced Raman spectroscopy of insect nuclear polyhedrosis virus. J. Raman Spectrosc. 32, pp. 227230.

Barenfanger, J., Drake, N., Leon, N., Mueller, T., \& Troutt, T. J. (2000). Clinical and Financial Benefits of Rapid Detection of Respiratory Viruses: an Outcomes Study. Clin. Microbiol. 38, pp. 2824-2828.

Baudart, J., \& Lebaron, P. (2010). Rapid detection of Escherichia coli in waters using fluorescent in situ hybridization, direct viable counting and solid phase cytometry. Journal of Applied Microbiology 109(4), pp. 1253-1264.

Bharadwaj, R., Sai, V.V.R., Thakare, K., Dhawangale, A., Kundu, T., Titus, S., Verma, P.K., \& Mukherji, S. (2011). Evanescent wave absorbance based fiber optic biosensor for label-free detection of E. coli at 280nm wavelength. Biosensors and Bioelectronics 26, pp. 3367-3370.

Brassard, J., Seyer, K., Houde, A., Simard, C., \& Trottier, Y.-L. (2005). Concentration and detection of hepatitis A virus and rotavirus in spring water samples by reverse transcription-PCR. Journal of Virological methods 123, pp. 163-169.

Bruno, J.G., Carrillo, M.P., Phillips, T., \& Andrews, C.J. (2010). A Novel Screening Method for Competitive FRET-Aptamers Applied to E. coli Assay Development. J Fluoresc. 20, pp. 1211-1223.

Campàs, M., \& and Marty, J.-L. (2007). Highly sensitive amperometric immunosensors for microcystin detection in algae. Biosensors and Bioelectronics 22, pp. 1034-1040.

Campàs, M., Szydłowska, D., Trojanowicz, M., \& Marty, J.-L. (2007). Enzyme inhibitionbased biosensor for the electrochemical detection of microcystins in natural blooms of cyanobacteria. Talanta 72 (1), pp. 179-186. 
Centers for Diseases Control and Prevention [CDC]. (2010), Morbidity and Mortality Weekly Report, November 19th, Atlanta, USA.

Chen, S.-H., Wu, V.C.H., Chuang, Y.-C., \& Lin, C.-S. (2008). Using oligonucleotidefunctionalized $\mathrm{Au}$ nanoparticles to rapidly detect foodborne pathogens on a piezoelectric biosensor. Journal of Microbiological Methods 73, pp. 7-17.

Choi, J.W., Lee, W., Lee, D.B., Park, C.H., Kim, J.S., Jang, Y.H., \& Kim, Y. (2007). Electrochemical Detection of Pathogen Infection Using Cell Chip. Environ. Monit. Assess. 129, pp. 37-42.

Cooper, I.R., Meikle, S.T., Standen, G., Hanlon, G.W., \& Santin, M. (2009). The rapid and specific real-time detection of Legionella pneumophila in water samples using Optical Waveguide Lightmode Spectroscopy. Journal of Microbiological Methods 78, pp. 4044.

Dawan, S., Kanatharana, P., Wongkittisuksa, B., Limbut, W., Numnuam, A., Limsakul, C., \& Thavarungkul, P. (2011). Label-free capacitive immunosensors for ultra-trace detection based on the increase of immobilized antibodies on silver nanoparticles. Analytica Chimica Acta 699 (2), pp. 232-241.

Deobagkar, D.D., Limaye, V., Sinha, S., \& Yadava, R.D.S. (2005). Acoustic wave immunosensing of Escherichia coli in water. Sensors and Actuators B 104, pp. 85-89.

Diercks, S., Medlin, L.K., \& Metfies, K. (2008). Colorimetric detection of the toxic dinoflagellate Alexandrium minutum using sandwich hybridization in a microtiter plate assay. Harmful Algae 7, pp. 137-145.

Diercks-Horn, S., Metfies, K., Jäckel, S., \& Medlin, L.K. (2011). The ALGADEC device: A semi-automated rRNA biosensor for the detection of toxic algae. Harmful Algae 10, pp. 395-401.

Dinçkaya, E., Kınık, Ö., Sezgintürk, M.K., Altuğ, Ç., \& Akkoca, A. (2011). Development of an impedimetric aflatoxin M1 biosensor based on a DNA probe and gold nanoparticles. Biosensors and Bioelectronics 26 (9), pp. 3806-3811.

Ding Y., \& Mutharasan R. (2010). Highly Sensitive and Rapid Detection of Microcystin-LR in Source and Finished Water Samples Using Cantilever Sensors. Environmental Science and Technology 45(4), pp. 1490-1496.

Donaldson, K.A., Kramer, M.F., \& Lim, D.V. (2004). A rapid detection method for Vaccinia virus, the surrogate for smallpox virus. Biosensors EBioelectronics 20, pp. 322-327.

Duplan, V., Frost, E., \& Dubowski, J.J. (2011). A photoluminescence-based quantum semiconductor biosensor for rapid in situ detection of Escherichia coli. Sensors and Actuators B, doi:10.1016/j.snb.2011.07.010.

European Commission [EC], Directive 2006/7/EC of the European Parliament and of the Council of 2006, February 15th, Concerning the management of bathing water quality and repealing Directive 76/160/EEC, In: Official Journal of the European Communities, L64, pp. 37-51.

EC, Council Directive 98/83/EC of 1998, November 3st. On the quality of water intended for human consumption, In: Official Journal of the European Communities, L330, pp. 32-54.

EC. Directive 2000/60/CE of 2000, October 23th. Water Frame Directive, In: Official Journal of European Commission, L327/1.

European Environment Agency [EEA]. (2010). The European environment, State and outlook 2010, Water resources: quantity and flows, In: Publications Office of the European Union, Luxembourg, (ISBN 978929213162 3). 
EEA, Wise TCM hazardous substances. 2011, February 18th. Available from: <http://www.eea.europa.eu/themes/water/interactive/tcm-hs>

Erdem, A., Kerman, K., Meric, B., Akarca, U.S., \& Ozsoz, M. (2000). Novel hybridization indicator methylene blue for the electrochemical detection of short DNA sequences related to the hepatitis B virus. Analytica Chimica Acta 422, pp. 139-149.

Eurostat, European Commission. (2010). Environmental statistics and accounts in Europe, In: Eurostat Statistical Book.

Ferrari, B.C., Stoner, K., \& Bergquist, P.L. (2006). Applying fluorescence based technology to the recovery and isolation of Cryptosporidium and Giardia from industrial wastewater streams. Water Research 40, pp. 541-548.

Fu, L., Zhang, K., Li, S., Wang, Y., Huang, T.-S., Zhang, A., \& Cheng, Z.-Y. (2010). In situ real-time detection of $\mathrm{E}$. coli in water using antibody-coated magnetostrictive microcantilever. Sensors and Actuators B 150, pp. 220-225.

Gau J.-J., Lan E.H., Dunn B., Ho C.-M., \& Woo J.C.S. (2001). A MEMS based amperometric detector for E. Coli bacteria using self-assembled monolayers. Biosensors $\mathcal{E}$ Bioelectronics 16, pp. 745-755.

Geng, P., Zhang, X., Teng, Y., Fu, Y., Xu, L., Xu, M., Jin, L., \& Zhang, W. (2011). DNA sequence-specific electrochemical biosensor based on alginic acid-coated cobalt magnetic beads for the detection of E. coli. Biosensors and Bioelectronics 26, pp. 33253330.

Gilgen, M., Germann, D., Lüthy, J., \& Hübner, Ph. (1997). Three-step isolation method for sensitive detection of enterovirus, rotavirus, hepatitis A virus, and small round structured viruses in water samples. International Journal of Food Microbiology 37, pp. 189-199.

Girones, R., Ferrus, M.A., Alonso, J.L., Rodriguez-Manzano, J., Calgua, B., Corrêa, A., Hundesa, A., Carratala, A., \& Bofill-Mas, S. (2010). Molecular detection of pathogens in water - The pros and cons of molecular techniques. Water Research 44, pp. 4325-4339.

Gregora J., \& Marsálek B. (2005). A Simple In Vivo Fluorescence Method for the Selective Detection and Quantification of Freshwater Cyanobacteria and Eukaryotic Algae. Acta hydrochim. hydrobiol. 33, pp. 142-148.

Guntupalli, R., Lakshmanan, R.S., Hu, J., Huang, T.S., Barbaree, J.M., Vodyanoy, V., \& Chin, B.A. (2007). Rapid and sensitive magnetoelastic biosensors for the detection of Salmonella typhimurium in a mixed microbial population. Journal of Microbiological Methods 70, pp. 112-118.

Guven, B., Basaran-Akgul, N., Temur, E., Tamer, U., \& Boyac, I.H. (2011). SERS-based sandwich immunoassay using antibody coated magnetic nanoparticles for Escherichia coli enumeration. Analyst 136, pp. 740-748.

Haughey, S.A., Campbell, K., Yakes, B.J., Prezioso, S.M., DeGrasse, S.L., Kawatsu, K., \& Elliott C.T. (2011). Comparison of biosensor platforms for surface plasmon resonance based detection of paralytic shellfish toxins. Talanta 85 (1), pp. 519-526.

Health Protection Agency. (2005). Enumeration of coliforms and Escherichia coli by Idexx (colilert 18) Quanti-trayTM. National Standard Method W 18. <http://www.hpastandardmethods.org.uk/pdf_sops.asp.> 
Henkel, J.H., Aberle, S.W., Kundi, M., \& Popow-Kraupp, T. (1997). Improved detection of respiratory syncytial virus in nasal aspirates by seminested RT-PCR. J. Med. Virol. 53, pp. 366-371.

Hong, P.-Y., Hwang, C., Ling, F., Andersen, G.L., LeChevallier, M.W., Liu, W.-T. (2010). Pyrosequencing analysis of bacterial biofilm communities in water meters of a drinking water distribution system. Applied and Environmental Microbiology 76, pp. 5631-5635.

Hu C., Gan N., He Z., \& Song L. (2008). A novel chemiluminescent immunoassay for microcystin (MC) detection based on gold nanoparticles label and its application to MC analysis in aquatic environmental samples. Intern. J. Environ. Anal. Chem. 88, pp. 267-277.

Huang, S., Pang, P., Xiao, X., He, L., Cai, Q., \& Grimes, C.A. (2008). A wireless, remote-query sensor for real-time detection of Escherichia coli O157:H7 concentrations. Sensors and Actuators B 131, pp. 489-495.

Huang, Y., Dong, X., Liu, Y., Lic, L.-J., \& Chen, P. (2011). Graphene-based biosensors for detection of bacteria and their metabolic activities. Journal of Materials Chemistry 21, pp. 12358-12362.

Hunter P., Lee J., Nichols G., Rutter M., Surman S., Weldon L., Biegon D., Fazakerley T., Drobnewski F., \& Morrell P. (2001). Fate of Mycobacterium avium Complex in Drinking Water Treatment and Distribution Systems. Research report DWI $70 / 2 / 122$.

Ilic, B., Yang, Y., \& Craighead, H. G. (2004). Virus detection using nanoelectromechanical devices. Appl. Phys. Lett.85, pp. 2604-2606.

International Organization for Standardization [ISO]. (2005). ISO 8199: 2005, Water quality General Guidance on the enumeration of microorganisms by culture.

Jing G., Polaczyk A., Oerther D.B., \& Papautsky I. (2007). Development of a microfluidic biosensor for detection of environmental mycobacteria. Sensors and Actuators B 123, pp. 614-621.

Karsunke X.Y.Z., Niessner R., \& Seidel, M. (2009). Development of a multichannel flowthrough chemiluminescence microarray chip for parallel calibration and detection of pathogenic bacteria. Anal Bioanal Chem 395, pp. 1623-1630.

Kattke, M.D., Gao, E.J., Sapsford, K.E., Stephenson, L.D., \& Kumar, A. (2011). FRET-Based Quantum Dot Immunoassay for Rapid and Sensitive Detection of Aspergillus amstelodami. Sensors 11, pp. 6396-6410.

Kormas, K., Neofitou, C., Pachiadaki, M., \& Koufostathi, E. (2010). Changes of the bacterial assemblages throughout an urban drinking water distribution system. Environmental Monitoring Assess. 165, pp. 27-38.

Kuznetsov, Y.G., Daijogo, S., Zhou, J., Semler, B.L., \& McPherson, A. (2005). Atomic force microscopy analysis of icosahedral virus RNA. J. Mol. Biol. 347, pp. 41-52.

Kwon, H.-J., Dean, Z.S., Angus S.V., \& Yoon, J.-Y. (2010). Lab-on-a-chip for Field Escherichia coli Assays: Long-term Stability of Reagents and Automatic Sampling System. JALA - Journal of the Association for Laboratory Automation 15, pp. 216-223.

Lassiter, K., Wang, R., Lin, J., Lum, J., Srinivasan, B., Lin, L., Lu, H., Hargis, B., Bottje, W., Tung, S., Berghman, L., \& Li, Y. (2009). Comparison study of an impedance biosensor and rRT-PCR for detection of avian influenza H5N2 from infected chickens. Program Book of PSA 2009 Annual Meeting, Raleigh, NC, July, 2009. 
Leonard, P., Hearty, S., Brennan, J., Dunne, L., Quinn, J., Chakraborty, T., \& O'Kennedy, R. (2003). Advances in biosensors for detection of pathogens in food and water. Enzyme and Microbial Technology 32, pp. 3-13.

Li, K., Lai, Y., Zhang, W., \& Jin, L. (2011A). $\mathrm{Fe}_{2} \mathrm{O}_{3} @ \mathrm{Au}$ core/shell nanoparticle-based electrochemical DNA biosensor for Escherichia coli detection. Talanta 84, pp. 607-613.

Li, S., Chen, J., Cao, H., Yao, D., \& Liu, D. (2011B). Amperometric biosensor for aflatoxin B1 based on aflatoxin-oxidase immobilized on multiwalled carbon nanotubes. Food Control 22 (1), pp. 43-49.

Li, X.X., Cao, C., Han, S.J., \& Sim, S.J. (2009). Detection of pathogen based on the catalytic growth of gold nanocrystals. Water Research 43, pp. 1425-1431.

Lin, H.-Y., Tsao, Y.-C., Tsai, W.-H., Yang, Y.-W., Yan, T.-R., \& Sheu, B.-C. (2007). Development and application of side-polished fiber immunosensor based on surface plasmon resonance for the detection of Legionella pneumophila with halogens light and $850 \mathrm{~nm}$-LED. Sensors and Actuators A 138, pp. 299-305.

Lindner, P., Molz, R., Yacoub-George, E., \& Wolf, H. (2009). Rapid chemiluminescence biosensing of microcystin-LR. Analytica Chimica Acta 636 (2), pp. 218-223.

Liu Y., \& Li Y. (2002). Detection of Escherichia coli O157:H7 using immunomagnetic separation and absorbance measurement. Journal of Microbiological Methods 51, pp. 369- 377.

Liu, X., Cheng, Z., Fan, H., Ai, S., \& Han R. (2011). Electrochemical detection of avian influenza virus $\mathrm{H} 5 \mathrm{~N} 1$ gene sequence using a DNA aptamer immobilized onto a hybrid nanomaterial-modified electrode. Electrochimica Acta 56 (18), pp. 6266-6270.

Loge, F.J., Thompson, D.E., Call, D.R. (2002). PCR Detection of Specific Pathogens in Water: A Risk-Based Analysis. Environ. Sci. Technol. 36, pp. 2754-2759.

Long F., He M., Zhu A.N., \& Shi H.C. (2009). Portable optical immunosensor for highly sensitive detection of microcystin-LR in water samples. Biosensors and Bioelectronics 24, pp. 2346-2351.

Long, F., He, M., Zhu, A., Song, B., Sheng, J., \& Shi, H. (2010). Compact quantitative optic fiber-based immunoarray biosensor for rapid detection of small analytes. Biosensors and Bioelectronics 26 (1), pp. 16-22.

Loypraserta, S., Thavarungkul, P., Asawatreratanakul, P., Wongkittisuksa, B., Limsakul, C., \& Kanatharana, P. (2008). Label-free capacitive immunosensor for microcystin-LR using self-assembled thiourea monolayer incorporated with Ag nanoparticles on gold electrode. Biosensors and Bioelectronics 24 (1), pp. 78-86.

Lum, J., \& Li, Y. (2010). Rapid detection of avian influenza H5N1 virus using impedance measurement of immuno-reaction coupled with RBC amplification. Master Thesis, Pub. N. ${ }^{\circ} 1485925$, University of Arkansas.

Luo, Y., Nartker, S., Miller, H., Hochhalter, D., Wiederoder, M., Wiederoder, S., Setterington, E., Drzal, L.T., \& Alocilja, E.C. (2010). Surface functionalization of electrospun nanofibers for detecting E. coli O157:H7 and BVDV cells in a direct-charge transfer biosensor. Biosensors and Bioelectronics 26, pp. 1612-1617.

Metfies, K., Huljic, S., Lange, M., \& Medlin, L.K. (2005). Electrochemical detection of the toxic dinoflagellate Alexandrium ostenfeldii with a DNA-biosensor. Biosensors and Bioelectronics 20, pp. 1349-1357.

Miranda-Castro, R., de-los-Santos-Álvarez, N., Lobo-Castañón, M.J., Miranda-Ordieres, A.J., \& Tuñón-Blanco, P. (2009). PCR-coupled electrochemical sensing of Legionella pneumophila. Biosensors and Bioelectronics 24, pp. 2390-2396. 
Mons, C., Dumètre, A., Gosselin, S., Galliot, C., \& Moulin, L. (2009). Monitoring of Cryptosporidium and Giardia river contamination in Paris area. Water Research 43, pp. 211-217.

Nayak, M., Kotian, A., Marathe, S., \& Chakravortty, D. (2009). Detection of microorganisms using biosensors- A smarter way towards detection techniques. Biosensors and bioelectronics 25, pp. 661-667.

O'Shea, M. K., Ryan, M.A.K., Hawksworth, A.W., Alsip, B.J., \& Gray, G.C. (2005). Symptomatic Respiratory Syncytial Virus Infection in Previously Healthy Young Adults Living in a Crowded Military Environment. Clin. Infect. Dis. 41, pp. 311-317.

Orozco, J., \& Medlin, L.; 2011b. Electrochemical performance of a DNA-based sensor device for detecting toxic algae. Sensors and Actuactors B 153, pp. 71-77.

Orozco, J., Baudart, J., \& Medlin, L.K. (2011). Evaluation of probe orientation and effect of the digoxigenin-enzymatic label in a sandwich hybridization format to develop toxic algae biosensors. Harmful Algae 10 (5), pp. 489-494.

Park, E.J., Lee, J.-Y., Kim, J.H., Lee, C.J., Kim, H.S., \& Min, N.K. (2010). Investigation of plasma-functionalized multiwalled carbon nanotube film and its application of DNA sensor for Legionella pneumophila detection. Talanta 82, pp. 904-911.

Park, S., Kim, H., Paek, S.-H., Hong, J.W., \& Kim, Y.-K. (2008). Enzyme-linked immuno-strip biosensor to detect Escherichia coli O157:H7. Ultramicroscopy 108, pp. 1348- 1351.

Paterson R.R.M., Kelley J., \& Gallagher M. (1997). Natural occurrence of aflatoxins and Aspergillus flavus (LINK) in water. Lett. Appl. Microbiol. 25, pp. 435-436.

Poitelon, J.-B., Joyeux, M., Welté, B., Duguet, J.-P., Prestel, E., DuBow, M. (2010). Variations of bacterial $16 \mathrm{~S}$ rRNA phylotypes prior to and after chlorination for drinking water production from two surface water treatment plants. J. Ind. Microbiol. Biotechnol. 37, pp. 117-128.

Pyo, D., \& Jin, J. (2007). Production and Degradation of Cyanobacterial Toxin in Water Reservoir, Lake Soyang. Bull. Korean Chem. Soc. 28 (5), pp. 800-804.

Pyo, D., Choi, J., Hong, J., \& Oo, H.H. (2006). Rapid Analytical Detection of Microcystins Using Gold Colloidal Immunochromatographic Strip. Journal of Immunoassay $\mathcal{E}$ Immunochemistry 27, pp. 291-302.

Pyo, D., Huang, Y., Kim, Y., \& Hahn, J.H. (2005). Ultra-Sensitive Analysis of Microcystin-LR Using Microchip Based Detection System. Bull. Korean Chem. Soc. 200526 (6), pp. 939-942.

Queirós, R.B., Silva, S.O., Noronha, J.P., Frazão, O., Jorge, P., Aguilar, G., Marques, P.V.S., \& Sales, M.G.F. (2011). Microcystin-LR detection in water by the Fabry-Pérot interferometer using an optical fibre coated with a sol-gel imprinted sensing membrane. Biosensors and Bioelectronics 26, pp. 3932-3937.

Rasooly, A., \& Herold, K.E. (2006) Biosensors for the Analysis of Food- and Waterborne Pathogens and Their Toxins. Journal of AOAC International 89, pp. 873-883.

Revetta, R., Pemberton, A., Lamendella, R., Iker, B., Santo Domingo, J.W. (2010). Identification of bacterial populations in drinking water using 16S rRNA-based sequence analyses. Water Research 44, pp. 1353-1360.

Russell R., Paterson M., \& Lima N. (2005). Fungal Contamination of Drinking Water, In: Water Encyclopedia, John Wiley and Sons, Inc..

Russell, R., \& Paterson, M. (2007). Zearalenone production and growth in drinking water inoculated with Fusarium graminearum. Mycological Progress 6 (2), pp. 109-113. 
Russell, R., Paterson, M., \& Lima, N. (2010) The Weaponisation of Mycotoxins (Chapter 21). In: Mycotoxins in Food, Feed and Bioweapons. Springer-Verlag, Berlin, Heidelberg.

Sapsford, K.E., Ngundi, M.M., Moore, M.H., Lassman, M.E., Shriver-Lake, L.C., Taitt, C.R., \& Ligler, F.S. (2006). Rapid detection of foodborne contaminants using an Array Biosensor. Sensors and Actuators B 113, pp. 599-607.

Shanmukh, S., Jones, L., Driskell, J., Zhao, Y., Dluhy, R., \& Tripp, R.A. (2006). Rapid and Sensitive Detection of Respiratory Virus Molecular Signatures Using a Silver Nanorod Array SERS Substrate. Nanoletters 6 (11), pp. 2630-2636.

Sheng, J., He, M., Yu, S., Shi, H., \& Qian, Y. (2007). Microcystin-LR detection based on indirect competitive enzyme-linked immunosorbent assay. Front. Environ. Sci. Engin. China 1(3), pp. 329-333.

Sigee, D. C. (2005). Freshwater Microbiology. John Wiley and Sons, LTD, Manchester, UK.

Simpson, J.M., \& Lim, D.V. (2005). Rapid PCR confirmation of E. coli O157:H7 after evanescent wave fiber optic biosensor detection. Biosensors and Bioelectronics 21, pp. 881-887.

Smith, H.V., \& Nichols, R.A.B. (2010). Cryptosporidium: Detection in water and food. Experimental Parasitology 124, pp. 61-79.

Song, S., Wang, L., Li, J., Zhao, J., \& Fan, C. (2008). Aptamer-based biosensors. Trends in Analytical Chemistry 27, pp.108-117.

Soule, H., Genoulaz, O., Gratacap-Cavallier, B., Chevallier, P., Liu, J.-L., \& Seigneurin J.-M. (2000). Ultrafiltration ans reverse transcription-polymerase chain reaction: an efficient process for polivirus, rotavirus and hepatitis A virus detection in water. Water Research 34 (3), pp. 1063-1067.

Spichiger-Keller U.E. (1998). Chemical and Biochemical Sensors (Chapter 2), In: Chemical Sensors and Biosensors for Medical and Biological Applications, Weinheim, WCH-Wiley.

$\mathrm{Su}$, L., Jia, W., Hou, C., \& Lei, Y. (2011). Microbial biosensors: a review. Biosensors and bioelectronics 26, pp. 1788-1799.

Sun, H., Choy, T.S., Zhu, D.R., Yam, W.C., \& Fung, Y.S. (2009). Nano-silver-modified PQC/DNA biosensor for detecting E. coli in environmental water. Biosensors and Bioelectronics 24, pp. 1405-1410.

Sungkanak, U., Sappat, A., Wisitsoraat, A., Promptmas, C., \& Tuantranont, A. (2010). Ultrasensitive detection of Vibrio cholerae O1 using microcantilever-based biosensor with dynamic force microscopy. Biosensors and Bioelectronics 26, pp. 784-789.

Tang, H., Zhang, W., Geng, P., Wang, Q., Jin, L., Wu, Z., \& Lou, M. (2006). A new amperometric method for rapid detection of Escherichia coli density using a selfassembled monolayer-based bienzyme biosensor. Analytica Chimica Acta 562, pp. 190-196.

Tavares, T., Cardoso, D., \& Diederichsen de Brito, W. (2005). Vírus entéricos veiculados por água: aspectos microbiológicos e de controle de qualidade da água. Revisão 34, pp. 85-104.

Thiruppathiraja, C., Kamatchiammal, S., Adaikkappan, P., Santhosh, D.J., \& Alagar, M. (2011). Specific detection of Mycobacterium sp. genomic DNA using dual labeled gold nanoparticle based electrochemical biosensor. Analytical Biochemistry 417, pp. 73-79. 
Tobler N.E., Pfunder M., Herzog K., Frey J.E., \& Altwegg M. (2006). Rapid detection and species identification of Mycobacterium spp. using real-time PCR and DNAMicroarray. Journal of Microbiological Methods 66, pp. 116- 124.

Toze S. (1999). PCR and the Detection of Microbial pathogens in Water and Wastewater. Water. Research 33, pp. 3545-3556.

Turner, A.P.F., \& Piletsky S. (2005). Biosensors and biommimetic sensors for the detection of drugs, toxins and biological agents., In: NATO Security through Science Series, Springer Ed., Volume 1, pp. 261-272.

Vo-Dinh, T. (2007). Biosensors and biochips, In: Biomolecular sensing, processing and analysis, Volume I, pp. 3-20.

Vörös, J., Ramsden, J.J., Csucs, G., Szendrö, I., Textor M., \& Spencer, N.D. (2002). Optical Grating Coupler Biosensors. Biomaterials 23 (17), pp. 3699-3710.

Wang L., Chen W., Xu D., Shim, B.S., Zhu Y., Sun F., Liu L., Peng C., Jin Z., Xu C., \& Kotov N.A. (2009). Simple, rapid, sensitive, and versatile SWNT- Paper sensor for environmental toxin detection competitive ELISA. Nano Letters 9(12), pp. 4147-4152.

Wang, L., Liu, Q., Hu, Z., Zhang, Y., Wu, C., Yang, M., \& Wang, P. (2009). A novel electrochemical biosensor based on dynamic polymerase-extending hybridization for E. coli O157:H7 DNA detection. Talanta 78, pp. 647-652.

World Health Organization [WHO] and WASH Inter Agency Group. (2007) Questions \& Answers on potential transmission of avian influenza (H5N1) through water, In: Sanitation and Hygiene and ways to reduce the risks to human health.

WHO. (1999). Toxic Cyanobacteria in Water: A guide to their public health consequences, monitoring and management. E \& FN Spon, London.

WHO. (2006). Review of latest available evidence on potential transmission of avian influenza (H5N1) through water and sewage and ways to reduce the risks to human health, In: Water, Sanitation and Health Public Health and Environment, Geneva.

WHO. (2011). Global Alert and Response Programme. Cholera outbreaks: Cholera outbreaks in the Democratic Republic of Congo (DRC) and the Republic of Congo, July 22nd, 2011.

Wildeboer, D., Amirat, L., Price, R.G., \& Abuknesha, R.A. (2010). Rapid detection of Escherichia coli in water using a hand-held fluorescence detector. Water Research 44, pp. 2621-2628.

Wolter, A., Niessner, R., \& Seidel, M. (2008). Detection of Escherichia coli O157:H7, Salmonella typhimurium, and Legionella pneumophila in Water Using a Flow-Through Chemiluminescence Microarray Readout System. Anal. Chem. 80, pp. 5854-5863.

Xia, Y., Deng, J., \& Jiang, L. (2010). Simple and highly sensitive detection of hepatotoxin microcystin-LR via colorimetric variation based on polydiacetylene vesicles. Sensors and Actuators B: Chemical145 (2), pp. 713-719.

Xia, Y., Zhanga, J., \& Jiang, L. (2011). A novel dendritic surfactant for enhanced microcystinLR detection by double amplification in a quartz crystal microbalance biosensor. Colloids and Surfaces B: Biointerfaces 86 (1), pp. 81-86.

$\mathrm{Xu}$, J., Suarez, D., \& Gottfried, D. (2007). Detection of Avian Influenza Virus Using An Interferometric Biosensor. Analytical and Bioanalytical Chemistry 389, pp. 1193-1199. 
Xue, X., Pan, J., Xie, H., Wang, J., \& Zhang, S. (2009). Fluorescence detection of total count of Escherichia coli and Staphylococcus aureus on water-soluble CdSe quantum dots coupled with bacteria. Talanta 77, pp. 1808-1813.

Yakes, B.J., Prezioso, S., Haughey, S.A., Campbell, K., Elliott, C.T., \& DeGrasse, S.L. (2011) An improved immunoassay for detection of saxitoxin by surface plasmon resonance biosensors. Sensors and Actuators B: Chemical 156 (2), pp. 805-811.

Yáñez M.A, Valor C., \& Catalán V. (2006). A simple and cost-effective method for the quantification of total coliforms and Escherichia coli in potable water. Journal of Microbiological Methods 65, pp. 608-611.

Ye, Y.K., Zhao, J.H., Yan, F., Zhu, Y.L., \& Ju, H.X. (2003). Electrochemical behavior and detection of hepatitis B virus DNA PCR production at gold electrode. Biosensors and Bioelectronics 18, pp. 1501-1508.

Yoo, S.K., Lee, J.H., Yun, S.-S., Gu, M.B., \& Lee, J.H. (2007). Fabrication of a bio-MEMS based cell-chip for toxicity monitoring. Biosensors and Bioelectronics 22, pp. 1586-1592.

Yoon, J.-Y., Han, J.-H., Choi, C.Y., Bui, M., \& Sinclair, R.G. (2009). Real-Time Detection of Escherichia coli in Water Pipe Using a Microfluidic Device with One-Step Latex Immunoagglutination Assay. Transactions of the ASABE, 52(3), pp. 1031-1039.

Yu J., Liu Z., Liu Q., Yuen K.T., Mak A.F.T., Yang M., \& Leung P. (2009). A polyethylene glycol (PEG) microfluidic chip with nanostructures for bacteria rapid patterning and detection. Sensors and Actuators A 154, pp. 288-294.

Yu, C.Y., Ang, G.Y., Chua, A.L., Tan, E.H., Lee, S.Y., Falero-Diaz, G., Otero, O., Rodríguez, I., Reyes, F., Acosta, A., Sarmiento, M.E., Ghosh, S., Ramamurthy, T., Yean, C.Y., Lalitha, P., \& Ravichandran, M. (2011). Dry-reagent gold nanoparticle-based lateral flow biosensor for the simultaneous detection of Vibrio cholerae serogroups $\mathrm{O} 1$ and O139. Journal of Microbiological Methods 86, pp. 277-282.

Yuan, J., Deng, D., Lauren, D.R., Aguilar, M.-I., \& Wu, Y. (2009). Surface plasmon resonance biosensor for the detection of ochratoxin A in cereals and beverages. Analytica Chimica Acta 656 (1-2), pp. 63-71.

Zhang, F., Yang, S.H., Kang, T.Y., Cha, G.S., Nam, H., \& Meyerhoff, M.E. (2007). A rapid competitive binding nonseparation electrochemical enzyme immunoassay (NEEIA) test strip for microcystin-LR (MCLR) determination. Biosensors and Bioelectronics 22 (7), pp. 1419-1425.

Zheng, Y.Z., Hyatt, A., Wang, L.F., Eaton, B.T., Greenfield, P.F., \& Reid, S.J. (1999). Quantification of recombinant core-like particles of bluetongue virus using immunosorbent electron microscopy. Virol. Methods 80, pp. 1-9.

Zhou, G., Wen, S., Liu, Y., Li, R., Zhong X., Feng, L., Wang, L., \& Cao, B. (2011). Development of a DNA microarray for detection and identification of Legionella pneumophila and ten other pathogens in drinking water. International Journal of Food Microbiology 145, pp. 293-300. 


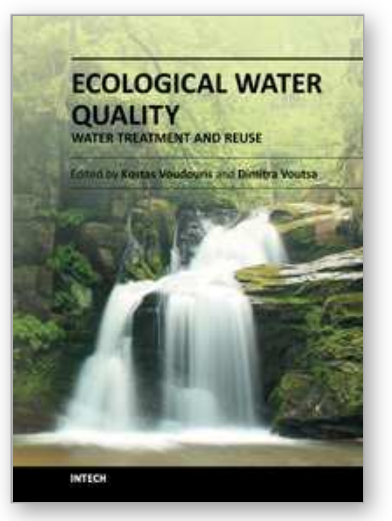

\author{
Ecological Water Quality - Water Treatment and Reuse \\ Edited by Dr. Voudouris
}

ISBN 978-953-51-0508-4

Hard cover, 496 pages

Publisher InTech

Published online 16, May, 2012

Published in print edition May, 2012

This book attempts to cover various issues of water quality in the fields of Hydroecology and Hydrobiology and present various Water Treatment Technologies. Sustainable choices of water use that prevent water quality problems aiming at the protection of available water resources and the enhancement of the aquatic ecosystems should be our main target.

\title{
How to reference
}

In order to correctly reference this scholarly work, feel free to copy and paste the following:

Raquel B. Queiros, J.P. Noronha, P.V.S. Marques and M. Goreti F. Sales (2012). Emerging (Bio)Sensing Technology for Assessing and Monitoring Freshwater Contamination - Methods and Applications, Ecological Water Quality - Water Treatment and Reuse, Dr. Voudouris (Ed.), ISBN: 978-953-51-0508-4, InTech, Available from: http://www.intechopen.com/books/ecological-water-quality-water-treatment-and-reuse/emerging-biosensing-technology-for-assessing-and-monitoring-freshwater-contamination-methods-and-ap

\section{INTECH}

open science | open minds

\author{
InTech Europe \\ University Campus STeP Ri \\ Slavka Krautzeka 83/A \\ 51000 Rijeka, Croatia \\ Phone: +385 (51) 770447 \\ Fax: +385 (51) 686166 \\ www.intechopen.com
}

\author{
InTech China \\ Unit 405, Office Block, Hotel Equatorial Shanghai \\ No.65, Yan An Road (West), Shanghai, 200040, China \\ 中国上海市延安西路65号上海国际贵都大饭店办公楼 405 单元 \\ Phone: +86-21-62489820 \\ Fax: $+86-21-62489821$
}


(C) 2012 The Author(s). Licensee IntechOpen. This is an open access article distributed under the terms of the Creative Commons Attribution 3.0 License, which permits unrestricted use, distribution, and reproduction in any medium, provided the original work is properly cited. 